\title{
Justice Stevens, Habeas Jurisdiction, and the War on Terror
}

\author{
Daniel A. Farber*
}

The Bush Administration chose Guantanamo as a detention site in the belief that the military base was immune from federal habeas jurisdiction, leading to a protracted dispute between the Executive Branch, the Supreme Court, and Congress. Justice Stevens played an important role in this struggle over federal habeas jurisdiction, writing two critical majority opinions and an important dissent. Justice Scalia countered Justice Stevens's two majority opinions with fervent dissents. Examining the clash between the two Justices is well worthwhile not only because of the importance of the scope of habeas jurisdiction, but also because of the light it may shed on their different analytic approaches.

Much of this clash was about the interpretation of statutes rather than large philosophical questions, so any analysis must delve into technicalities if it is to be illuminating. This Article gives particular attention to a seemingly arcane and technical battle over the retroactivity of jurisdiction-stripping statutes. Not surprisingly, where Justice Scalia saw a bright-line rule, which he accused the Court of wantonly trammeling, Justice Stevens instead saw a more pragmatic standard. Justice Scalia accused Justice Stevens of warping the law to achieve a desired result, and careful attention to his accusation is required in order to assess Justice Stevens's rulings.

A close examination of precedent supports Justice Stevens's view and rebuts Justice Scalia's accusation of lawlessness. Although traces of support for Justice Scalia are present in some older cases, those cases provide muddled support for his approach, and Justice Stevens was right to distinguish them and rely instead on the Court's modern jurisprudence regarding retroactivity. Thus, Justice Scalia was wrong to attack Justice

- Sho Sato Professor of Law and Chair, Energy and Resources Group, at the University of California, Berkeley. Tess Hand-Bender provided valuable research assistance on this Article. An earlier draft was presented at the UC Davis Law Review Symposium on the Honorable John Paul Stevens, March 6, 2009. Diane Amann provided helpful comments on a previous draft. 
Stevens for violating existing law and trumpet his own approach as truer to the rule of law. Rather, it was Justice Stevens's reasoning that was more faithful to the rule of law.

\section{TABLE OF CONTENTS}

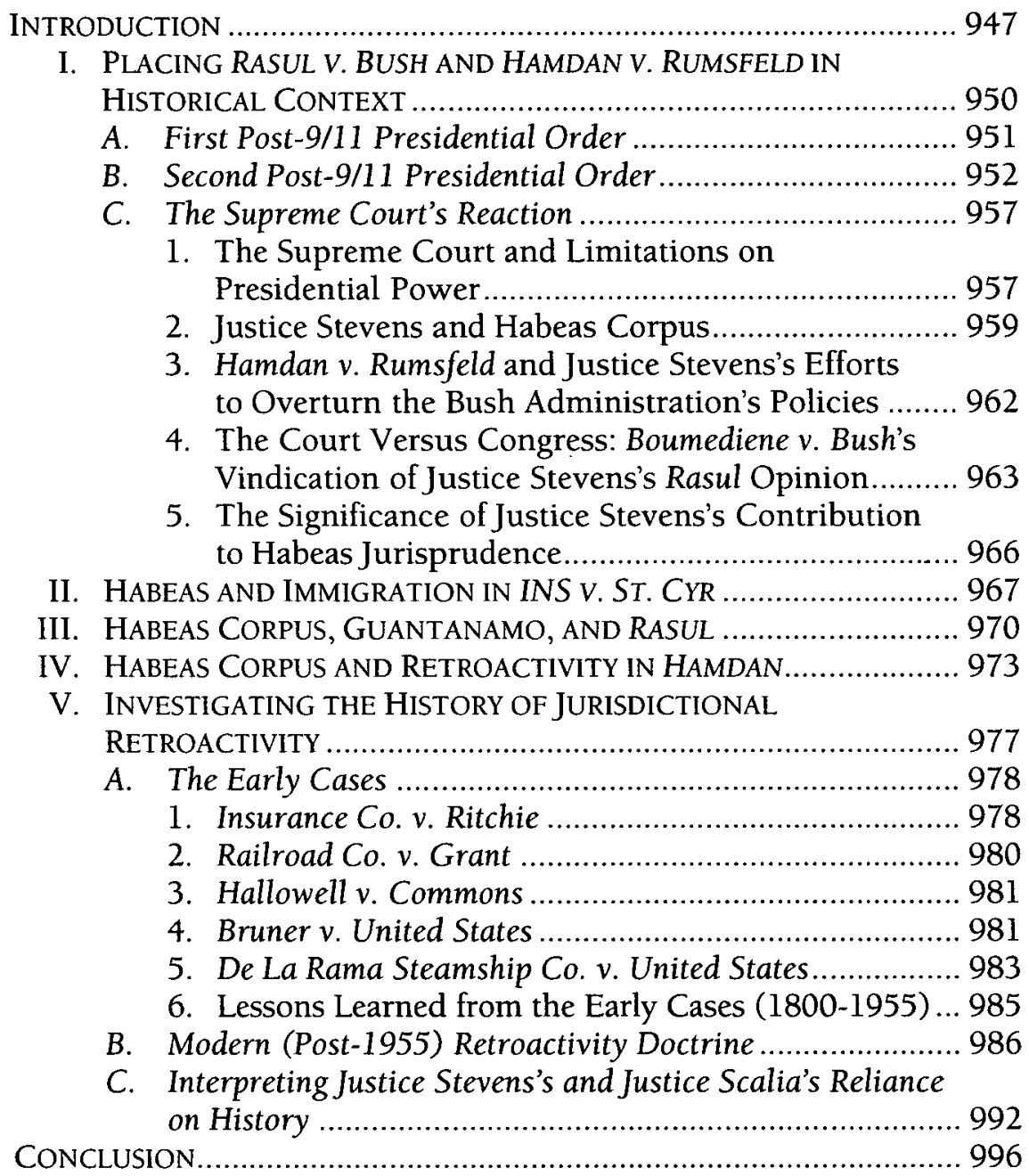




\section{INTRODUCTION}

The government's response to the September 11, 2001 ("9/11") attacks and the "war on terror" have raised serious civil liberties concerns. ${ }^{1}$ Perhaps the most fundamental concerns center on the government's treatment and prosecution of individuals detained as suspected terrorists. ${ }^{2}$ The Executive Branch initially claimed the power to deal with these detainees free from judicial or congressional restrictions and without any constitutional requirement of due process. ${ }^{3}$ Almost none of the detainees were American residents or citizens, so the Executive Branch's detention policy did not directly affect the public. ${ }^{4}$ What makes these issues fundamental, however, is that they impact the applicability of the rule of law in a period of emergency. ${ }^{5}$ The Executive Branch's detention policy triggered a prolonged confrontation between the judiciary and President George W. Bush. Later in the dispute, the confrontation evolved into a conflict among all three branches of government. Taking action contrary to both the courts and the Executive Branch, Congress attempted to oust the courts from the dispute while imposing some restrictions of its own on the President, only to be thwarted in turn by the Supreme Court. ${ }^{6}$

Justice Stevens played an important role in this struggle over federal habeas jurisdiction, writing two critical majority opinions and an

1 For an excellent collection of background materials on these issues, see NORMAN ABRAMS, ANTI-TERRORISM AND CRIMINAL ENFORCEMENT (2d ed. 2005).

2 For background on these issues, see JACK GOLDSMITH, THE TERROR PRESIDENCY: LAW AND JUDGMENT INSIDE THE BUSH AdMINISTRATION 11-13 (2007); JANE MAYER, THE DARK SIDE: THE INSIDE STORY OF HOW THE WAR ON TERROR TURNED INTO a WAR ON AMERICAN IDEALS (2008); Dawn E. Johnsen, The Story of Hamdan v. Rumsfeld: Trying Enemy Combatants by Military Commission, in PRESIDENTIAL POWER STORIEs 447 (Christopher H. Schroeder \& Curtis A. Bradley eds., 2009).

3 See GoldSMITH, supra note 2, at 106-07.

4 See Interactive Graphic, The Guantanamo Docket: Countries of Citizenship, N.Y. TIMES, http://projects.nytimes.com/guantanamo/detainees/by-country/page/3 (last visited Oct. 17, 2009) (reporting that only 1 of 779 individuals detained at Guantanamo was U.S. citizen).

${ }_{5}$ For a discussion of the rule of law as a concept, see Terry Nardin, Emergency Logic: Prudence, Morality, and the Rule of Law, in EMERGENCIES AND THE LIMITS OF LEGALITY 97 (Victor V. Ramraj ed., 2008).

6 The Court's decisions since $9 / 11$ have been a departure from its previous history of deferring to the president in deciding civil liberties issues during crises involving national security. See L.A. Powe, Jr., The Role of the Court, in SECURITY V. LiberTY: CONFlicts Between Civil Liberties and National SeCURity in American History 165, 182 (Daniel A. Farber ed., 2008). 
important dissent. His opinions are notable for their general avoidance of rhetorical highlights and their devotion to close legal analysis of statutory language and precedents. Justice Scalia countered Justice Stevens's two majority opinions with fervent dissents. Examining the clash between these two Justices is worthwhile not only because of the importance of the legal issues regarding habeas jurisdiction over Guantanamo detainees, but also because of the light it may shed on the different analytic approaches that these two Justices have espoused throughout their careers. ${ }^{7}$

Jurisdictional issues may seem like technicalities, but they were at the core of the ongoing disputes over the legality of the treatment of detainees after 9/11. The writ of habeas corpus is the historic method of ensuring that the government detains individuals only in accordance with the law. Thus, in practical terms, the limits of habeas jurisdiction over executive detention are also the limits of the rule of law. As we will see in Part I, the Executive Branch chose Guantanamo as a detention site in the hope of creating a legal black hole within which constitutional and other legal rights had no meaning because habeas would become unavailable. A slender Supreme Court majority, often led by Justice Stevens, pushed back and ultimately insisted that habeas jurisdiction extended to Guantanamo with or without statutory support.

Debates will no doubt continue over the legality of the detention programs that the Bush Administration initiated, and even more so over their utility. This Article does not address the substance of those disputes, important as they are. Instead, it focuses on how the Court, under the leadership of Justice Stevens, parried a threat to the rule of

7 In my view, Justice Stevens's opinions in INS v. St. Cyr, 533 U.S. 289 (2001), Rasul v. Bush, 542 U.S. 466 (2004), and particularly Hamdan v. Rumsfeld, 548 U.S. 557 (2006), demonstrate that he represents what Fallon and Meltzer call the common law approach, "courts as having a creative, discretionary function in adapting constitutional and statutory language." Richard H. Fallon, Jr. \& Daniel J. Meltzer, Habeas Corpus Jurisdiction, Substantive Rights, and the War on Terror, 120 HARV. L. REV. 2029, 2033 (2007); see also id. at 2050 (using St. Cyr to exemplify common law approach). In contrast, Justice Scalia clearly embodies their "agency" approach, under which "courts should regard themselves as the agents of those who enacted, or ratified, pertinent statutory or constitutional provisions; they should assume that those provisions were framed to be as determinate as possible; and they should minimize judicial creativity." See id. at 2033. A similar jurisprudential division is drawn in Kathleen M. Sullivan, Foreword: The Justices of Rules and Standards, 106 HARV. L. Rev. 22 (1992), using Stevens as an example of standards-based jurisprudence and Scalia as the example of rules-based jurisprudence. As Sullivan says, "If Justice Scalia leads the charge for rules on the current Court, Justice Stevens is his most consistent, standard-bearing antagonist." Id. at 87. 
law that was implicit in the Bush Administration's efforts to make the U.S. base at Guantanamo invisible to the legal system. Justice Stevens deserves considerable credit for his role in this defense of the rule of law.

Part I of this Article outlines the background and historical context for the clashing opinions of Justices Stevens and Scalia. Part II examines an important Justice Stevens opinion in INS v. St. Cyr concerning habeas jurisdiction just prior to 9/11. That opinion provided a clear signal of his approach and prompted a scathing dissent by Justice Scalia, presaging their later dispute. Part III examines how Justices Stevens and Scalia diverged on habeas jurisdiction in Rasul v. Bush. Part IV examines how Justices Stevens and Scalia differed over jurisdictional retroactivity in Hamdan $v$. Rumsfeld. Part V delves more deeply into the historical issues that divided the two Justices, concluding that the weight of the evidence clearly supports Justice Stevens's view of jurisdictional retroactivity. This Article ends with a few concluding thoughts about the simple virtue of ensuring government compliance with the rule of law.

This Article has three purposes. The first is to explain Justice Stevens's pivotal role in the post-9/11 disputes over detention. His opinions played a critical part in foiling efforts to create a legal black hole at Guantanamo. The Article's second purpose is to investigate competing claims over whether the Supreme Court's rulings themselves were consistent with the rule of law as opposed to being driven by policy views of the Bush Administration's actions. The Article delves in detail into one key legal issue: a dispute over statutory retroactivity that had to be resolved before the Court could consider the validity of the Bush Administration's military trial system pertaining to detainees. The third purpose is to investigate the differing jurisprudential approaches of Justices Stevens and Scalia, who disagreed in all but the first of the Guantanamo cases. In particular, the two Justices have had very different views about habeas jurisdiction and have offered different approaches to interpreting the relevant statutes. Justice Scalia, following his general philosophy, has sought to apply clear-cut rules (for example, that statutes restricting federal jurisdiction always apply to pending cases unless Congress clearly states otherwise). Justice Stevens has used a more pragmatic, context-sensitive approach. In practice, which Justice has proven to be more protective of the rule of law? Answering that question requires, among other things, a closer look at the historical context, which is the subject of Part I. 
I. Placing Rasul V. Bush and hamdan V. Rumsfeld in Historical CONTEXT

This Part discusses President Bush's actions following the 9/11 attacks and places the events leading up to the Supreme Court's detainee cases in context. In particular, this Part examines the President's two post-9/11 memoranda on detention and then explores the Supreme Court's responses to the Bush Administration's actions. Understanding this history places Justice Stevens's clash with Justice Scalia in context.

The detention issue arose only a few months after $9 / 11$. Soon after the terrorist attacks, Congress passed a resolution authorizing the President to "use all necessary and appropriate force" against "nations, organizations, or persons" that he determined "planned, authorized, committed, or aided" in the attacks. ${ }^{8}$ The President then ordered an invasion of Afghanistan to attack al Qaeda and the Taliban regime.

The Bush Administration's constitutional vision shaped its response to $9 / 11$. Vice President Dick Cheney played a key role in formulating administrative policy, which he viewed in part as an opportunity to strengthen presidential prerogatives. ${ }^{9}$ As Dawn Johnsen, the current nominee to head the Office of Legal Counsel in the Obama Administration, has observed, Vice President Cheney and Secretary of Defense Donald Rumsfeld received the support of a group of legal advisors whose "views on executive authority countenanced measures that not only limited individual liberty, but that also realigned ... the balance of powers among the three branches, principally by shifting power from Congress to the President." ${ }^{10}$ As John Yoo has explained, the Bush Administration's actions also arose from a perception that "9/11 attacks revealed a new kind of threat" and that "our old laws and policies did not address this new enemy, and that we need to start developing a new set of rules to confront it." ${ }^{\prime 1}$ This Part describes the Bush Administration's response in detail and then covers the Supreme Court's response.

8 Authorization for the Use of Military Force, Pub. L. No. 107-40, \& 2, 115 Stat. 224,224 (2001).

9 See Johnsen, supra note 2, at 450-51.

10 Id. at 451 .

11 JOHN YOO, War By Other MEANS: AN INSIDER'S ACCOUNT OF THE WAR ON TERROR 46-47 (2006). 


\section{A. First Post-9/11 Presidential Order}

This Subpart examines the Bush Administration's first effort to deal with the issue of detention. The Bush Administration attempted to implement new policies regarding detainees that reflected the increased power of the Executive Branch. On November 13, 2001, President Bush issued a military order regarding the detention of terrorists to address the perceived $9 / 11$ threat. ${ }^{12}$ Section 1 of the order stated:

To protect the United States and its citizens, and for the effective conduct of military operations and prevention of terrorist attacks, it is necessary for individuals subject to this pursuant to section 2 hereof to be detained, and, when tried, to be tried for violations of the laws of war and other applicable laws by military tribunals. ${ }^{13}$

As it later became clear, the purpose of detention was as much to provide an opportunity for aggressive interrogation as it was to incapacitate dangerous individuals who might present threats to the United States. ${ }^{14}$ Thus, the Bush Administration opposed giving the detainees access to lawyers or legal process because such access might give them hope and, thus, interfere with the interrogation process. ${ }^{15}$

Section 2 defined who was subject to this order, or, more precisely, authorized the President to make such determinations in the future. The President merely needed to make a written finding that there was "reason to believe" that a person was a member of al Qaeda, had engaged in acts of international terrorism against the United States, or had harbored such individuals. ${ }^{16}$ The President must also have found that "it [was] in the interest of the United States that such individual be subject to this order." ${ }^{17}$ Essentially, then, the targets of the order consisted of everyone who had assisted al Qaeda or engaged in terrorism against the United States - or more precisely, those whom

12 Detention, Treatment, and Trial of Certain Non-Citizens in the War Against Terrorism, 66 Fed. Reg. 57,833 (Nov. 13, 2001), available at http:/georgewbushwhitehouse.archives.gov/news/releases/2001/11/20011113-27.html.

13 Id.

14 See Johnsen, supra note 2, at 455.

15 As Johnsen explains, the Administration viewed complete isolation as important to inculcating a sense of hopelessness to the detainees and making them more responsive to questioning. People who have outside contacts may be less amenable to coercive questioning. See id.

1666 Fed. Reg. 57,833, 57,834.

17 Id. 
the President suspected of doing so. Individuals covered by this order did not include American citizens.

After section 2, the order prescribed the conditions and consequences of detention. Section 3 provided for military detention of these individuals, who were to be "treated humanely" and "afforded adequate food, drinking water, shelter, clothing, and medical treatment." 18 Section 4 then provided that "[a]ny individual subject to this order shall, when tried, be tried by military commission for any and all offenses triable by military commission that such individual is alleged to have committed and may be punished in accordance with the penalties provided under applicable law, including life imprisonment or death." ${ }^{19}$ Subsection (c) sketched the procedures for such trials, which were to provide a "full and fair trial."20 Finally, section 7 of the order provided that individuals "shall not be privileged to seek any remedy or maintain any proceeding, directly or indirectly, or to have any such remedy or proceeding sought on the individual's behalf, in (i) any court of the United States, or any State thereof, (ii) any court of any foreign nation, or (iii) any international tribunal." ${ }^{21}$ Section 7 could not limit the jurisdiction of foreign courts or international tribunals and, thus, its effect on U.S. courts was at best unclear.

The upshot of the order was that the Executive Branch gained significant authority over detention decisions. Detention decisions would be purely executive; conditions of detention would be based on a voluntary adherence to humanitarian values rather than on legal constraints; trial would be conducted by the military rather than civilian courts; and courts would be excluded from reviewing executive decision. These resulted in a breathtaking assertion of the power of the executive to act free from any domestic legal restrictions. As the next subpart will show, the Bush Administration encountered a potential international constraint a few months later, the Geneva Conventions.

\section{B. Second Post-9/11 Presidential Order}

This Subpart discusses the Bush Administration's efforts to address the procedural and substantive rights afforded to detainees under the Geneva Conventions. Three months after the issuance of the first

\footnotetext{
18 Id.

19 Id.

20 Id.

21 Id. at $57,835-36$.
} 
order, the President supplemented his first order with a classified order that only became available to the public several years later. In the second order, President Bush rejected the application of the Geneva Conventions to supporters of al Qaeda, whether captured during the Afghanistan conflict or elsewhere. Al Qaeda was a nonstate actor, whereas the Taliban in effect represented the government of Afghanistan. Despite the distinction, the two forces often fought side by side on the ground in Afghanistan. Taliban members might have been placed in any one of three categories: lawful combatants entitled to prisoner of war status; unlawful combatants because of their failure to wear conventional uniforms and, therefore, subject to punishment under the laws of war; or a paramilitary militia having no status under the Geneva Conventions and, therefore, legally subject to whatever treatment the United States chose as a matter of policy. Members of al Qaeda engaging in terrorist acts outside of Afghanistan were at least unlawful combatants under the Geneva Conventions, but al Qaeda forces in Afghanistan might arguably have shared the status of Taliban forces to the extent the Taliban received recognition under the Geneva Conventions. However, apart from the question of whether the detainees were protected against harsh treatment or even execution, the question remained whether they were entitled both to a hearing to determine their status and to procedural protections before being punished for war crimes.

In the first paragraph of the order, the President concluded that "the war against terrorism ushers in a new paradigm, one in which groups with broad, international reach commit horrific acts against innocent civilians, sometimes with the support of states." ${ }^{22}$ It continued, "Our nation recognizes that this new paradigm - ushered in not by us, but by terrorists - requires new thinking in the law of war, but thinking that should nevertheless be consistent with the principles of Geneva."23

The second paragraph of the order considered the substantive application of the Geneva Conventions to al Qaeda and the Taliban. As to al Qaeda, the order concluded, "I accept the legal conclusion of the Department of Justice and determine that none of the provisions of Geneva apply to our conflict with al Qaeda in Afghanistan or

22 Memorandum from George $W$. Bush on Humane Treatment of Taliban and al Qaeda Detainees to the Vice President, the Sec'y of State, the Sec'y of Def, the Att'y Gen., Chief of Staff to the President, Dir. of Cent. Intelligence, Assistant to the President for Nat'l Sec. Affairs, Chairman of the Joint Chiefs of Staff para. 1 (Feb. 7th, 2002), available at http:/www.pegc.us/archive/White_House/bush_memo_20020207_ed.pdf.

23 Id. 
elsewhere throughout the world because, among other reasons, al Qaeda is not a High Contracting Party to Geneva." ${ }^{24}$

President Bush was faced with a separate substantive issue concerning the Taliban. In paragraph $2 \mathrm{c}$ of the order, the President rejected the sweeping argument that because Afghanistan is a failed state, the Geneva Conventions did not apply to the conflict as a whole. Furthermore, he did not provide Taliban supporters with prisoner of war status, notwithstanding contrary arguments ${ }^{25}$ by the U.S. State Department. Nevertheless, "as a matter of policy," the order directed the armed forces to "continue to treat [all] detainees humanely and, to the extent appropriate and consistent with military necessity, in a manner consistent with the principles of Geneva."

This order was based in part on the advice of then-White House Counsel (and later Attorney General) Alberto Gonzales. In his memorandum on the subject, ${ }^{26}$ Gonzales argued that "the war against terrorism is a new kind of war. ${ }^{\text {27 }}$ Gonzales continued:

The nature of the new war places a high premium on other factors, such as the ability to quickly obtain information from captured terrorists and their sponsors in order to avoid further atrocities against American civilians, and the need to try terrorists for war crimes such as wantonly killing civilians. In my judgment, this new paradigm renders obsolete Geneva's strict limitations on questioning of enemy prisoners and renders quaint some of its provisions requiring that captured enemy be afforded such things as commissary privileges, scrip (i.e., advances of monthly pay), athletic uniforms, and scientific instruments. ${ }^{28}$

Gonzales argued, however, that several factors would continue to constrain the U.S. armed forces in their treatment of al Qaeda and Taliban detainees: "(i) its commitment to treat the detainees humanely and, to the extent appropriate and consistent with military necessity,

24 Id. para. 2.

25 Memorandum from Colin L. Powell on Applicability of the Geneva Convention to the Conflict in Afghanistan to Counsel to the President, Assistant to the President for Nat'l Sec. Affairs 1 (Jan. 26, 2002), available at http://www.slate.com/features/ whatistorture/pdfs/020126.pdf.

26 Memorandum from Alberto R. Gonzales on Decision Re Application of the Geneva Convention on Prisoners of War to the Conflict with al Qaeda and the Taliban to the President (Jan. 25, 2002), available at http://www.slate.com/features/ whatistorture/pdfs/020125.pdf.

27 Id. at 2.

28 Id. 
in a manner consistent with the principles of [Geneva], (ii) its applicable treaty obligations, (iii) minimum standards of treatment universally recognized by the nations of the world, and (iv) applicable military regulations regarding the treatment of detainees." ${ }^{29}$ The "humane treatment" commitment was presumably purely a matter of American policy based on the country's own moral values. The other factors arguably had some legal standing because universal standards of treatment can be considered international common law, and valid military regulations are (by definition) legally binding on military personnel.

The Gonzales memo was sharply contested by the legal adviser to the U.S. State Department, William H. Taft IV, who argued that the Geneva Conventions should have applied to Taliban detainees in Afghanistan. ${ }^{30}$ But the President ultimately sided with Gonzales, except to the extent that he was willing to classify Taliban members as unlawful combatants under the Geneva Conventions rather than as being entirely outside their purview.

Besides eliminating the substantive provisions of the Geneva Conventions as applied to al Qaeda, the President's decision also had the effect of eliminating the Conventions' procedural protections that would otherwise have applied to Taliban and al Qaeda detainees. ${ }^{31}$ When applicable, the Geneva Conventions not only provide substantive protections, but also require significant procedural safeguards beyond those promised in the President's first order. Under Article 5, "[s]hould any doubt arise as to whether persons, having committed a belligerent act and having fallen into the hands of the enemy," constitute POWs, "such persons shall enjoy the protection of the present Convention until such time as their status has been determined by a competent tribunal." ${ }^{32}$ Thus, Article 5 might apply to the Taliban forces and perhaps to some of their al Qaeda supporters in Afghanistan as to whom some doubt existed about their status under the Geneva Conventions. Other al Qaeda supporters might be

29 Id. at 4.

30 Memorandum from William H. Taft IV on Comments on Your Paper on the Geneva Convention to Counsel to the President l (Feb. 2, 2002), available at http:/www.nytimes.com/packages/html/politics/20040608_DOC.pdf.

31 For a detailed critique of the President's position and its legal rationale, see Derek Jinks \& David Sloss, Is the President Bound by the Geneva Conventions?, 90 CORNELl L. REV. 97 (2004). For an enlightening discussion of the application of the Geneva Conventions to modern terrorism, see MARK OSIEL, THE END OF RECIPROCITY: TERROR, TORTURE, AND THE LAW OF WAR (2009).

32 Geneva Convention Relative to the Treatment of Prisoners of War art. 5, Aug. 12, 1949, 6 U.S.T. 3316, 75 U.N.T.S. 135 [hereinafter Geneva III]. 
unconnected with any conventional military force and, hence, at least arguably not subject to any doubt about their lack of coverage under the Geneva Conventions.

Common Article 3 imposes other requirements in an "armed conflict not of an international character occurring in the territory of one of the High Contracting Parties." In such conflicts, punishment is not allowed "without previous judgment pronounced by a regularly constituted court, affording all the judicial guarantees which are recognized as indispensable by civilized parties. ${ }^{33}$ An important issue of interpretation is whether the United States' conflicts with al Qaeda or the Taliban in Afghanistan, or the more general struggle against al Qaeda, qualify as an "armed conflict not of an international character" under this provision. ${ }^{34}$

Failure to comply with the Geneva Conventions would constitute potentially more than an international embarrassment if they are found to apply. Under a federal statute, the War Crimes Act, ${ }^{35}$ U.S. nationals or members of the armed forces who commit war crimes are subject to life imprisonment or the death penalty if the victim dies. War crimes include "any conduct ... defined as a grave breach" in the Geneva Conventions and any violation of Common Article $3 .^{36}$ The Third Geneva Convention, Article 130, lists "wilfully depriving a prisoner of war of the rights of fair and regular trial prescribed in this Convention" as a grave breach. ${ }^{37}$ Thus, failure to follow proper procedures before imposing punishment on detainees could potentially be a serious federal offense, even a capital one. The President sought to avoid these potential consequences - and with them the need to provide procedural protection - by ruling the Geneva Conventions completely inapplicable to al Qaeda and its supporters, and by classifying Taliban soldiers as unlawful combatants about whom no doubt existed.

The Bush Administration viewed its actions as being untrammeled by either domestic legal restrictions or the international rules of the

33 Id. art. 3. Common Article 3 is "common" to all four Geneva Conventions. See Geneva Convention Relative to the Protection of Civilian Persons in Time of War, Aug. 12, 1949, 6 U.S.T. 3516, 75 U.N.T.S. 287; Geneva III, supra note 32; Geneva Convention for the Amelioration of the Condition of Wounded, Sick and Shipwrecked Members of Armed Forces at Sea, Aug. 12, 1949, 6 U.S.T. 3217, 75 U.N.T.S. 85; Geneva Convention for the Amelioration of the Condition of the Wounded and Sick in Armed Forces in the Field, Aug. 12, 1949, 6 U.S.T. 3114, 75 U.N.T.S. 31.

${ }^{34}$ See Geneva III, supra note 32, art. 3.

3518 U.S.C. \& 2441 (2006).

36 Id.

37 Geneva 11l, supra note 32, art. 130. 
Geneva Conventions, but there was no guarantee that the federal courts would agree with these legal views. Rather than taking the risk of losing on the merits, the Bush Administration hoped to avoid any judicial review of these actions by situating the detainees at Guantanamo, a military base under complete American control, but technically not part of the United States. Because the United States completely controlled Guantanamo, it provided a desirable setting for handling the detainees free from possible interference by host governments, unlike other military bases in foreign countries. Because it was outside of the United States, Guantanamo was also arguably beyond the authority of the federal courts. Thus, the Bush Administration's first line of defense against legal challenge was the argument that habeas jurisdiction stopped at the U.S. border. ${ }^{38}$ Although the Bush Administration had its own view of habeas jurisdiction, the ultimate legal determination would be for the Supreme Court.

\section{The Supreme Court's Reaction}

This Subpart examines the Court's response to the Bush Administration's stance on detainees, a response in which Justice Stevens played a critical role. He wrote important majority opinions and a powerful dissent rallying the Justices who opposed the Bush Administration's position. Distinguishing prior precedent that seemed to favor the Bush Administration, he crafted the basis for the Court's rulings upholding habeas jurisdiction over the detainees. Without those rulings, detainee issues would have been immune from any judicial oversight.

\section{The Supreme Court and Limitations on Presidential Power}

The Supreme Court proved resistant to the President's broad assertion of authority. Justice Stevens consistently sided against the Bush Administration, while Justice Scalia supported it with almost equal consistency. The one exceptional case where the two agreed was the first of the Court's Guantanamo rulings. That case involved the domestic detention of an American citizen without any hearing or prospect for trial.

38 " $[\mathrm{T}]$ he lawyers at the Department of Justice's Office of Legal Counsel were doing their very best to accede to what was rumored to be Secretary Rumsfeld's request for 'the legal equivalent to outer space.'" KaREN J. GREEnBERG, THE LEAST WORST Place: GuANTANAMO's FirSt 100 DAYs 7 (2009). 
In June 2004, the Supreme Court split in its rationale in Hamdi $v$. Rumsfeld, ${ }^{39}$ but agreed almost unanimously on the key point: eight Justices rejected the government's position that it had an unreviewable right to detain "enemy combatants" without a hearing. ${ }^{40}$ The individual detained in that case, Yaser Hamdi, was an American citizen, which undoubtedly made the government's argument more difficult. ${ }^{41}$ This decision came in the aftermath of shocking revelations about the treatment of American prisoners in the Iraqi prison of $\mathrm{Abu}$ Graib. ${ }^{42}$ It was probably no coincidence that the story of prisoner abuse at Abu Graib had broken only hours after the oral argument in the case. ${ }^{43}$ At this point, the Justices recognized that President Bush's promise to provide detainees with humane treatment had clearly not been fulfilled. Four Justices, led by Justice O'Connor, held that Hamdi was entitled to some form of due process hearing. ${ }^{44}$ Justice O'Connor's opinion acknowledged a power of detention, but also began to stake out limits; for example, detention could not be solely for the purposes of interrogation and could not extend beyond the armed conflict in question. ${ }^{45}$ Justice O'Connor was thus faced with the difficult question of how to determine whether an individual fell within what she called the "narrow category" of unlawful combatants. ${ }^{46}$ She attempted to provide a fair process for determining the facts, allowing the government to begin the process by filing factual affidavits, while giving the detainee the chance to provide evidence in rebuttal ${ }^{47}$

Justice O'Connor's opinion was positioned between two more absolutist views. Four other Justices, in two different opinions, would have held the detention of a citizen such as Hamdi squarely unlawful - a group of Justices that included both Justice Scalia and Justice Stevens. At the other end of the spectrum, Justice Thomas, who appeared to envision no limit to presidential wartime powers, voted in

39 See 542 U.S. 507 (2004).

40 See id. at 508.

41 See id. at 507.

42 See Diane Marie Amann, Abu Graib, 153 U. PA. L. Rev. 2085, 2090-98 (2005); Johnsen, supra note 2, at 458-59.

43 See MAYER, supra note 2, at 260-61. For a more detailed description of the Abu Graib incident, see Laura A. Dickinson, Abu Graib: The Battle over Institutional Culture and Respect for International Law Within the U.S. Military, in INTERNATIONAL LAW STORIES 405 (John E. Noyes et al. eds., 2007).

44 See Hamdi, 542 U.S. at 508.

45 See id. at 533-34, 537.

${ }^{46}$ Id. at $517,534-39$.

47 Id. 
favor of the government's position ${ }^{48}$ The bottom line was that eight Justices rejected Justice Thomas's extreme view of presidential power. As discussed above, the President had asserted sweeping, if not unqualified, power to detain potential supporters of al Qaeda and the Taliban. Rejecting this argument, the Court held that presidential power was limited and that detainees were legally entitled to at least some procedural protections. ${ }^{49}$

\section{Justice Stevens and Habeas Corpus}

In addition, the Court issued two rulings on habeas jurisdiction on the same day as Hamdi, both of which reveal Justice Stevens's discomfort with the policies of the Bush Administration. In the first case, Rasul v. Bush, ${ }^{50}$ the Court held that the writ of habeas corpus extended to Guantanamo under the habeas statute. Justice Stevens's opinion for the Court distinguished statutory jurisdiction from the question of whether the Constitution required granting Guantanamo detainees access to the writ. ${ }^{51}$ These jurisdictional issues were not relevant in Hamdi because the government had chosen to confine American citizens like Hamdi within the United States rather than at Guantanamo. But Justice Stevens's Rasul opinion was a pivotal ruling in terms of the rights of the Guantanamo detainees, because otherwise they would have had no access to federal courts in which to challenge their treatment. Justice Scalia wrote in dissent for himself, the Chief Justice, and Justice Thomas.

In the second case, Padilla v. Rumsfeld ${ }^{52}$ the Court considered the petition of an American citizen, Jose Padilla, who had been detained

48 Hamdi is notable as evidence that ideology is not everything, even in the hardest constitutional cases. The critical vote for Justice O'Connor's position was Justice Breyer, commonly considered a member of the liberal block. Chief Justice Rehnquist, a strong conservative voice, also allied himself with Justice O'Connor's centrist views. In the meantime, the two most conservative members of the Court (Justices Thomas and Scalia) came to diametrically opposite conclusions, and Justice Scalia was joined by Justice Stevens, the most liberal member of the Court.

49 See id. at 533-34.

so 542 U.S. 466,468 (2004).

51 Id. at 478-79. Fallon and Meltzer, perhaps the leading authorities on habeas, find Rasul's "specific outcome ... entirely plausible and normatively defensible within the Common Law Model. . . ." Fallon \& Meltzer, supra note 7, at 2059. They add, "[I]t was a modest and sensible step for the Court to hold as a matter of statutory construction that federal courts can entertain petitions from aliens detailed in a location that, for functional purposes, might as well be American territory." Id. at 2059-60.

52542 U.S. 426,431 (2004). 
while reentering the United States. When the Second Circuit appeared close to ordering his release, the government hastily transferred him to the naval brig in South Carolina. Thus, at the time of the actual filing, the petitioner was no longer detained in New York, and the Bush Administration argued that the New York federal judge lacked jurisdiction and that the case would have to be refiled in South Carolina. The Court held that a habeas petition could only be brought in the place of custody, which gave the government the advantage of the more favorable forum in the Fourth Circuit. ${ }^{53}$ In addition to dissecting the jurisdictional issues, ${ }^{54}$ Justice Stevens's dissent in Padilla emphasized the critical importance of access to habeas:

At stake in this case is nothing less than the essence of a free society. Even more important than the method of selecting the people's rulers and their successors is the character of the constraints imposed on the Executive by the rule of law. Unconstrained executive detention for the purpose of investigating and preventing subversive activity is the hallmark of the Star Chamber. Access to counsel for the purpose of protecting the citizen from official mistakes and mistreatment is the hallmark of due process..$^{55}$

Justice Stevens also criticized the use of prolonged detention without counsel as a means of acquiring information. "[I]f this Nation is to remain true to the ideals symbolized by its flag," he wrote, "it must not wield the tools of tyrants even to resist an assault by the forces of tyranny." ${ }^{56}$

53 Id. at 449-51.

54 Justice Stevens's dissent argued that the exceptional nature of Padilla's case and its national implications required the Court to reach its merits. Id. at 455 (Stevens, J., dissenting). Justice Stevens argued that "this case is singular not only because it calls into question decisions made by the Secretary himself, but also because those decisions have created a unique and unprecedented threat to the freedom of every American citizen." See id. at 461 . He cited a series of cases where exceptions are found to the majority's "bright-line rule" requiring that the respondent be the immediate custodian of the prisoner. Id. at 460-63. Justice Stevens advocated a "functional approach" to the custody requirement, contending that the writ should not be stifled by formalistic applications of procedural requirements. See id. at 461. Justice Stevens argued that under this approach, the Secretary of Defense was the appropriate respondent because he was entrusted by the President with control over Padilla's location, and Rumsfeld had sufficient contacts with the Southern District to be served process there, making the petition properly filed in the Southern District. See id. at 462.

55 Id. at 465.

56 Id. 
In contrast, Justice Scalia joined the majority opinion in Padilla, which held that habeas jurisdiction was defeated because the petition was filed in New York after the government had already spirited the prisoner away to South Carolina. Unfortunately, the majority countenanced the government's opportunistic manipulation of the judicial process. This narrow procedural holding turned out to be less important, however, than the concerns about violation of the rule of law expressed in Justice Stevens's dissent. These concerns were significant because the majority of the Court later shared them, as the next subpart will demonstrate.

Justice Stevens was not the only one to be disturbed by the government's use of isolation and prolonged detention as an interrogation technique, as seen in the response of a Bush Administration official in Hamdi. Providing the opportunity for prolonged interrogation was a key purpose of the detention program. But the results could be unpalatable even to supporters of the Bush Administration. Jack Goldsmith visited the naval brig in South Carolina during his term as head of the Office of Legal Counsel. Goldsmith had not been involved in the creation of the Bush Administration's detention policies or the drafting of the legal memoranda defending the validity of those policies, but he was a staunch supporter of the Administration. During the visit, he observed Hamdi in his prison cell via closed-circuit television. Although he continued to believe that the government had the right to detain Hamdi, he felt that something was profoundly amiss:

It seemed unnecessarily extreme to hold a twenty-two-year-old foot soldier in a remote wing of a run-down prison in a tiny cell, isolated from almost all human contact and with no access to a lawyer. "This is what habeas corpus is for," I thought to myself, somewhat embarrassed at the squishy sentiment. $^{57}$

Indeed, as it turned out, Hamdi's detention seems to have been completely pointless. The government later turned him over to the Saudis, who subsequently released him. ${ }^{58}$

As the journalist Jane Mayer explained, Rasul and Hamdi were serious setbacks that "might have served as important warning signs to a more flexible administration," but "rather than adjusting its course, the Bush White House dug in deeper." 59 Hamdi indicated that

57 GOLDSMITH, supra note 2, at 102.

58 MAYER, supra note 2, at 303.

59 Id. at 302 . 
detainees might have at least some constitutional rights, and Rasul rebuffed the Bush Administration's efforts to make Guantanamo a lawfree zone in which it could do as it pleased. Goldsmith's reaction to Hamdi's detention and his criticism of the Bush Administration's response to the Court's early rulings are indications of the difficulties that the Administration would later face in the Supreme Court. Moderate conservatives such as Justices Kennedy and O'Connor, like Goldsmith, found the Bush Administration's positions too extreme.

\section{Hamdan v. Rumsfeld and Justice Stevens's Efforts to Overturn} the Bush Administration's Policies

Two years after Hamdi, Rasul, and Padilla, in Hamdan v. Rumsfeld, ${ }^{60}$ Justice Stevens led the Court in overturning the Bush Administration's efforts to evade legal restrictions. His opinion built on Rasul and also showed that the Court was not inclined to acquiesce to congressional or presidential efforts to limit its jurisdiction. Although the opinion did not address the constitutionality of congressional restrictions on habeas, it clarified that the Court viewed such restrictions with a jaundiced eye. This Article will return to a detailed discussion of the jurisdictional aspect of Hamdan in Part IV, focusing on the question of whether a jurisdiction-stripping statute enacted while the case was pending should be applied retroactively.

Hamdan was much more sweeping than Hamdi in terms of the substantive restrictions placed on the detention process. Hamdan involved the use of military commissions to try enemy combatants under the first presidential order discussed earlier. In an opinion by Justice Stevens, the Court held that the President lacked the power to establish military tribunals under congressional enactments and under the Geneva Conventions. ${ }^{61}$ Specifically, the Court held that the military commission convened to try Salim Ahmed Hamdan, who was allegedly Osama bin Laden's driver and bodyguard, lacked the power to proceed because its structure and procedures both violated the Geneva Conventions and the Uniform Code of Military Justice. ${ }^{62}$

After reviewing the history and authority for military commissions, Justice Stevens concluded that the President had the authority to

60548 U.S. 557 (2006).

61 For a detailed discussion of the Court's use of the Geneva Conventions, see Oona A. Hathaway, Hamdan v. Rumsfeld: Domestic Enforcement of International Law, in INTERNATIONAL LAW StORIES 229 (John E. Noyes et al. eds., 2007).

62 Hamdan, 548 U.S. at 567; see Diane Marie Amann, Punish or Surveil, 16 Transnat'l L. \& Contemp. Probs. 873, 893-900 (2007). 
convene such commissions, but only in circumstances justified by the law of war. ${ }^{63}$ Justice Stevens also emphasized that such commissions were bound by the common law of war. ${ }^{64}$ In Part V of his opinion (joined only by Justices Souter, Ginsberg, and Breyer), Justice Stevens examined the traditional types of military commissions convened historically, concluding that Hamdan's tribunal was a "law-of-war commission" convened typically on the battlefield and with jurisdiction limited to offenses in violation of the laws of war. ${ }^{65}$ Justice Stevens reasoned that because the charging document alleged a conspiracy beginning long before $9 / 11$ and lacked allegations regarding overt acts that actually violated the laws of war, the military commission was unlawful and unnecessary. ${ }^{66}$ Writing for the majority, Justice Stevens also reasoned that regardless of whether Hamdan had been charged with an offense generally cognizable by military commissions, the commission here did not have the authority to proceed because its procedures were illegal. ${ }^{67}$ Summarizing the Court's holding, Justice Stevens concluded by stating that "in undertaking to try Hamdan and subject him to criminal punishment, the Executive is bound to comply with the rule of law that prevails in this jurisdiction." 68 Justice Scalia dissented, arguing that the Court lacked jurisdiction over the case, a position that will be discussed in detail later. He also rejected the legal attacks on the military tribunals on the merits.

\section{The Court Versus Congress: Boumediene v. Bush's Vindication of} Justice Stevens's Rasul Opinion

After Hamdan, Congress reacted by decisively stepping into the detainee issue. The Military Commissions Act of $2006^{69}$ ("MCA") modified the rules governing detainees while also attempting to limit judicial review. Some changes were favorable to the detainees. The

63 Hamdan, 548 U.S. at 590-93.

64 Id at 593-95.

65 Id. at 597.

66 Id. at $600,612-23$. Here Justice Stevens includes a lengthy argument, based on historical sources, precedent, and international law for why the conspiracy with which Hamdan was charged is not a war crime.

${ }^{67}$ Id. at 613. Justice Stevens found first that the procedures violate the Uniform Code of Military Justice (UCMJ) because they are a departure from traditional court martial procedures unjustified by military exigency. Id. at 625 . In a section only commanding a plurality - Part VI.D.v-vi - Justice Stevens also found that a provision of the Geneva Conventions applies to Hamdan, and that the procedures of the military commission do not meet its requirements. Id. at 635 .

68 Id.

69 Pub. L. No. 109-366, 120 Stat. 2600. 
MCA prohibited enemy combatants from invoking the Geneva Conventions as a source of rights. ${ }^{70}$ Instead, the MCA attempted to provide a fairer hearing by sending appeals to the Court of Military Commission Review rather than the Secretary of Defense and by protecting the military judges in tribunals from adverse career consequences. ${ }^{71}$ Congress also guaranteed the defendant's right to be present at all points in the proceeding, which was contrary to the President's first order, and allowed editing of classified material prior to introduction at trial. ${ }^{72}$ Other changes, however, favored the Bush Administration. The MCA allowed the use of some coerced statements against the defendant. ${ }^{73}$ Finally, the statute clearly stated that conspiracy to violate the laws of war was a separate offense; this point had been hotly contested previously by international law authorities. ${ }^{74}$

The MCA's most fundamental change - and the greatest victory for the Bush Administration - was a provision eliminating the writ of habeas corpus for any "alien detained by the United States who has been determined by the United States to have been properly detained as an enemy combatant or is awaiting such determination." ${ }^{75}$ The term enemy combatant was broadly defined to include anyone who provides "material support" for hostilities; moreover, the provision appeared to apply even to permanent residents of the United States. ${ }^{76}$ Thus, habeas was unavailable to any noncitizen who had provided material support for either al Qaeda or the Taliban, regardless of longterm residence or place of detention. ${ }^{77}$ The statute also attempted to oust the courts from independently interpreting the Geneva Conventions. Notably, however, Congress did not contest the Court's determination in Hamdan that the Geneva Conventions applied to the detainees. As John Yoo said, "[I]t is a rare and extraordinary thing for Congress to checkmate the Supreme Court as it did," and he wondered whether it would "serve as a sufficient warning to the courts not to meddle in the business of the political branches ...."78

Clearly, Congress's decision to step into the detainee issue did not deter the Court. The Court struck down the jurisdiction-stripping

\footnotetext{
${ }^{70}$ Id. \& $5(\mathrm{~g})$.

71 See id. \& $950 f$.

72 Id. § 949a, 949j.

73 Id. \& 949a(2)(C).

${ }^{74}$ Id. $\S 950 \mathrm{v}(\mathrm{a})(15)$.

75 Id. \& 7(e)(1).

${ }^{76}$ Id. \& $950 \mathrm{v}(\mathrm{a})(25)$.

77 See id.

78 Yoo, supra note 11 , at 164 .
} 
provision of the MCA in Boumediene v. Bush. ${ }^{79}$ In an opinion by Justice Kennedy, the Court held that the United States' de facto sovereignty over Guantanamo was sufficient to bring it within the scope of the constitutional guarantee of habeas and that the MCA was therefore a violation of the Suspension Clause of the Constitution. ${ }^{80}$ The opinion emphasized that liberty remains a key value even in the face of dangerous threats to national security:

Officials charged with daily operational responsibility for our security may consider a judicial discourse on the history of the Habeas Corpus Act of 1679 and like matters to be far removed from the Nation's present, urgent concerns. Established legal doctrine, however, must be consulted for its teaching. Remote in time it may be; irrelevant to the present it is not. Security depends upon a sophisticated intelligence apparatus and the ability of our Armed Forces to act and to interdict. There are further considerations, however. Security subsists, too, in fidelity to freedom's first principles. Chief among these are freedom from arbitrary and unlawful restraint and the personal liberty that is secured by adherence to the separation of powers. It is from these principles that the judicial authority to consider petitions for habeas corpus relief derives. ${ }^{81}$

Justice Stevens joined Justice Kennedy's opinion and did not write separately. But as a concurrence by Justice Souter explained, Boumediene was a predictable extension of Justice Stevens's opinion in Rasul. Technically, Rasul rested on statutory grounds whereas Boumediene rested on constitutional grounds, but the language in Rasul suggested fundamental objections to depriving detainees of habeas protections. Thus, as the concurring Justices said, "[N]o one who reads the Court's opinion in Rasul could seriously doubt that the jurisdictional question must be answered the same way in purely constitutional cases, given the Court's reliance on the historical background of habeas generally in answering the statutory question." 82 In a vehement dissent, Justice Scalia angrily predicted that the Court's decision will "almost certainly cause more Americans to be killed,"

\footnotetext{
79128 S. Ct. 2229, 2234-35 (2008).

80 See id. at 2251-53.

81 Id. at 2277.

82 Id. at 2278 (Souter, J., concurring).

83 Id. at 2294 (Scalia, J., dissenting).
} 
and that the "Nation will live to regret what the Court has done today." 84

\section{The Significance of Justice Stevens's Contribution to Habeas Jurisprudence}

It would take a lengthy book to deal with all of the issues raised in this line of cases and to appraise the significance of Justice Stevens's contribution in all its dimensions. Rather than attempting a hasty and superficial coverage of all of those issues, this Article focuses on a smaller but critical question relating to the interpretation of habeas laws. Hamdan provided the occasion for the Court to overturn the Bush Administration's effort to exempt its actions from the Geneva Conventions. But the Court would not have been able to reach this issue without first deciding that it had jurisdiction over the case. A congressional statute, the Detainee Treatment Act of $2005^{85}$ ("DTA"), purported to strip habeas jurisdiction over detainees from the courts. The Hamdan Court held, however, that this statute did not apply to pending cases such as Hamdan. As Part IV examines in detail, Justice Stevens carefully parsed the DTA in reaching this position, whereas Justice Scalia relied on a broad presumption favoring retroactivity that he viewed as supporting application of the jurisdiction-stripping law.

Interpretation of habeas statutes, and specifically of congressional restrictions on habeas, is itself a large subject which is covered at length in books on federal jurisdiction. To understand the dispute over jurisdiction in Hamdan, however, it is helpful to set it in the context of an important earlier case, INS v. St. Cyr, which is discussed next. That earlier case involved a strikingly similar dispute between Justice Stevens and Justice Scalia over how to interpret a statute that appeared to deprive the Court of jurisdiction over an important habeas issue.

One reason that looking to this earlier case is important is that historic issues such as the "war on terror" might lead judges to distort

84 Id. at 2307.

85 See Pub. L. No. 109-148, div. A, tit. X, §§ 1001-1006, 119 Stat. 2680, 2739-44. Congress also enacted a nearly identical version of the DTA as a component of the National Defense Authorization Act for Fiscal Year 2006, Pub. L. No. 109-163, div. A, tit. XIV, §§ 1401-1406, 119 Stat. 3136, 3474-80 - an appropriations authorization act that the President signed into law on January 6, 2006 (a week after he signed the original DTA into law). The December 2005 and January 2006 versions of the DTA are generally identical except for certain provisions in the section relating to training of Iraqi security forces (section 1006 of the 2005 DTA and section 1406 of the 2006 DTA). Compare Detainee Treatment Act of 2005, Pub. L. No. 109-148, § 1006, with National Defense Authorization Act for Fiscal Year 2006, Pub. L. No. 109-163, § 1406. 
their normal modes of legal analysis - thus, the famous saying that "hard cases make bad law." ${ }^{86}$ That distortion does not seem to have affected Justice Stevens and Justice Scalia's dispute over jurisdiction in Hamdan. On the contrary, their positions in Hamdan resonated deeply with their previously espoused views on habeas litigation in more technical cases outside of the public spotlight. Indeed, as shown in Part II, the two Justices had already rehearsed their competing approaches in a habeas case that preceded 9/11.

\section{HABEAS AND IMMIGRATION IN INS V. ST. CYR}

Although the post-9/11 cases reflect special concerns relating to national security and presidential power, they also reflect preexisting disputes among the Justices about how to interpret statutes involving habeas jurisdiction. This Part examines a pre-9/11 ruling in detail to place the Guantanamo cases in context as part of this ongoing debate over habeas jurisdiction. The case is also instructive about the gap between Justices Stevens and Scalia which resurfaced in Hamdan, where the two Justices debated whether a statute retroactively deprived the Court of jurisdiction over pending cases.

An immigration case decided just before $9 / 11$, INS v. St. Cyr, ${ }^{87}$ previews the later dispute between Justices Stevens and Scalia regarding habeas jurisdiction. ${ }^{88}$ The case involved the application of newly enacted restrictions on the availability of habeas for aliens in the context of deportation. As he later did in Hamdan, Justice Stevens closely parsed the restrictive statute and found that habeas jurisdiction remained available, while Justice Scalia complained that the ruling flouted a bright-line rule.

In Justice Stevens's majority opinion in St. Cyr, the Court held that the two statutes at issue in the case did not eliminate habeas jurisdiction over St. Cyr's claim and that the Attorney General retained waiver authority ${ }^{80}$ Before the passage of the statutes, the Antiterrorism and Effective Death Penalty Act of $1996^{90}$ ("AEDPA") and the Illegal

86 See N. Sec. Co. v. United States, 193 U.S. 197, 364 (1904) (Holmes, J., dissenting).

87533 U.S. 289 (2001).

88 St. Cyr is directly relevant to Hamdan and Boumediene because, as Fallon and Meltzer point out, it suggests constitutional doubts about the preclusion of judicial review for aliens who are held unconstitutionally. See Fallon \& Meltzer, supra note 7 , at 2062-64.

89 St. Cyr, 533 U.S. at 297.

90 Pub. L. No. 104-132, 110 Stat. 1214. 
Immigration Reform and Immigrant Responsibility Act of $1996^{91}$ ("IIRIRA"), the U.S. Attorney General had broad discretion to waive deportation of resident aliens. A lawful permanent U.S. resident, Enrico St. Cyr, pled guilty to a criminal charge that subjected him to deportation. He would have been eligible for a deportation waiver under the immigration law in effect at the time of his conviction, but his removal proceedings were commenced after the 1996 statutes took effect. The Attorney General claimed that those statutes withdrew his authority to grant St. Cyr a waiver. The Attorney General also claimed that the federal courts lacked jurisdiction to consider this issue.

In rejecting the Attorney General's arguments, the Court relied on a strong presumption in favor of judicial review of administrative action and on the longstanding rule requiring a clear and unambiguous statement of congressional intent to repeal habeas jurisdiction. In the Court's view, "Implications from statutory text or legislative history are not sufficient to repeal habeas jurisdiction; instead, Congress must articulate specific and unambiguous statutory directives to effect a repeal." ${ }^{92}$ These clear-statement rules were bolstered by the canon against interpreting statutes in ways that raise serious constitutional doubts. ${ }^{93}$ The Suspension Clause protects against legislative restrictions on habeas in deportation cases, ${ }^{94}$ and even in 1789 the type of question of law that St. Cyr raised would have been within the common law writ of habeas corpus. ${ }^{95}$ To conclude that the writ was no longer available in this context would have represented a marked departure from historical immigration law practice. ${ }^{96}$ Indeed, the Court said, "The fact that this Court would be required to answer the difficult question of what the Suspension Clause protects is in and of itself a reason to avoid answering the constitutional questions that would be raised by concluding that review was barred entirely." ${ }^{97}$ In

91 Pub. L. No. 104-208, 110 Stat. 3009-546.

92 St. Cyr, 533 U.S. at 299.

93 Id.

94 Id. at 300. Here, the Court relied on Heikkila v. Barber, 345 U.S. 229 (1953), which emphasizes that habeas is designed to protect constitutional rights and also distinguishes sharply between "judicial review" and habeas in the immigration setting. St. Cyr, 533 U.S. at 300.

95 See St. Cyr, 533 U.S. at 301.

96 Id. at 305. According to the Court, habeas had always been available to review the legality of Executive detention, citing Felker v. Turpin, 518 U.S. 651, 663 (1996), and habeas courts had addressed questions of law that arose in the discretionary relief context. St. Cyr, 533 U.S. at 305.

97 St. Cyr, 533 U.S. at 301 n.13. 
the Court's view, none of the 1996 provisions clearly negated jurisdiction under the general habeas provision. ${ }^{98}$

In his dissent, Justice Scalia observed that "it is crystal clear that the statute before us here bars criminal aliens from obtaining judicial review." clause, channeling all review through a procedure that did not apply in St. Cyr's case. The zipper clause was titled "Consolidation of questions for judicial review" and provided that "[j] udicial review of all questions of law and fact, including interpretation and application of constitutional and statutory provisions, arising from any action taken or proceeding brought to remove an alien from the United States... shall be available only in [the designated procedure]."100 Justice Scalia maintained that this preclusion of "judicial review" plainly encompassed habeas review.

In rejecting Justice Scalia's argument, Justice Stevens's majority opinion relied on statements in earlier cases distinguishing between "judicial review" and habeas in the immigration context to support a very narrow reading of the statute as referring only to "judicial review" in this narrow sense rather than the ordinary sense (which would encompass habeas). ${ }^{101}$ Justice Stevens's willingness to engage in this close parsing of the statutory terminology to avoid extinguishing habeas review presages his later opinion in Hamdan. As discussed later, the Hamdan opinion relied heavily on the fact that some other subsections, but not the one involved in the case, expressly applied to pending cases.

Part II of Justice Scalia's dissent was joined by Chief Justice Rehnquist and Justice Thomas, but not by Justice O'Connor, who expressed agreement only with Justice Scalia's statutory analysis. ${ }^{102}$ Justice Scalia argued in Part II that the Suspension Clause does not convey any right to habeas, but only guards against temporary suspensions of habeas jurisdiction once Congress has decided to grant it. ${ }^{103}$ In contrast, the majority read the same historical statements to support the "far more sensible view that the Clause was intended to preclude any possibility that 'the privilege itself would be lost' by either the inaction or the action of Congress." 104

\footnotetext{
98 Id. at 312.

99 Id. at 336 (Scalia, J., dissenting).

1008 U.S.C. $\S 1252$ (b)(9) (2006).

101 See St. Cyr, 533 U.S. at 312.

102 Id. at 326 (O'Connor, J., dissenting).

103 Id. at 337 (Scalia, J., dissenting).

104 Id. at 304 n.24 (majority opinion).
} 
St. Cyr was decided at the end of June 2001, less than three months before $9 / 11$. It provided a preview of the later debate about habeas in the context of detainees. It also contained a sign that should have given pause to the Bush Administration and its congressional supporters: Justice Kennedy, who clearly became the swing voter after Justice O'Connor left the Court, was part of the majority in St. Cyr. The case presaged Justice Kennedy's vote in Rasul and Hamdan, as well as hinting at the constitutional views expressed in his majority opinion in Boumediene. Whether the Justices would follow the habeasprotective approach mapped out in St. Cyr in the far more contentious area of national security was an open question. Part III provides the beginning of the answer to this question.

\section{HABEAS CORPUS, GUANTANAMO, AND RASUL}

The Bush Administration chose Guantanamo as a detention site in an attempt to block habeas jurisdiction, thereby preventing the detainees from raising any legal challenges to their treatment. The Administration's legal position had some support, but St. Cyr suggested that at least some of the Justices, including Justice Stevens, would be resistant to the Administration's restrictive view of habeas jurisdiction. This Part focuses on Justice Stevens's and Justice Scalia's divergent historical views of the writ of habeas corpus in Rasul.

The Court resolved the question of whether the existing habeas statute applied to Guantanamo in Rasul. The jurisdictional issue in Rasul was whether habeas extended to aliens outside of the United States, or at least those detained at Guantanamo. A World War II-era case suggested that the constitutional right to habeas might not include aliens outside of the United States, although citizens seemed to have access to habeas regardless of their geographic location. ${ }^{105}$ More specifically, as the Rasul Court explained, the earlier case "held that a Federal District Court lacked authority to issue a writ of habeas corpus to 21 German citizens who had been captured by U.S. forces in China, tried and convicted of war crimes by an American military commission headquartered in Nanking, and incarcerated in the Landsberg Prison in occupied Germany." 106 The Court held that the decision was inapplicable because it rested on the outmoded view that Congress had failed to confer habeas jurisdiction to judges for detainees outside of their own districts in all circumstances, requiring

105 Rasul v. Bush, 542 U.S. 466, 475-76 (2004) (citing Eisentrager v. Forrestal, 174 F.2d 961, 963 (D.C. Cir. 1949)).

106 Id. 
the Court to consider and reject the argument that the prisoners had a constitutional entitlement to habeas. ${ }^{107}$

Besides a careful dissection of the post-World War II development of habeas jurisdiction, Justice Stevens's opinion for the majority in Rasul also relied on earlier history:

Application of the habeas statute to persons detained at the base is consistent with the historical reach of the writ of habeas corpus. At common law, courts exercised habeas jurisdiction over the claims of aliens detained within sovereign territory of the realm, as well as the claims of persons detained in the so-called "exempt jurisdictions," where ordinary writs did not run, and all other dominions under the sovereign's control. As Lord Mansfield wrote in 1759, even if a territory was "no part of the realm," there was "no doubt" as to the court's power to issue writs of habeas corpus if the territory was "under the subjection of the Crown." Later cases confirmed that the reach of the writ depended not on formal notions of territorial sovereignty, but rather on the practical question of "the exact extent and nature of the jurisdiction or dominion exercised in fact by the Crown." 108

In his dissent, Justice Scalia attacked the majority opinion in no uncertain terms:

The consequence of this holding, as applied to aliens outside the country, is breathtaking. It permits an alien captured in a foreign theater of active combat to bring a [\$] 224I petition against the Secretary of Defense ... . The military is currently detaining over 600 prisoners at Guantanamo Bay alone; each detainee undoubtedly has complaints-real or contrived-about those terms and circumstances. ... From this point forward, federal courts will entertain petitions from these prisoners,

107 Justice Kennedy's concurrence in the judgment followed a different path but distinguished the World War II case on the grounds that the military base "is in every practical respect a United States territory, and it is one far removed from any hostilities," id. at 487, and that Guantanamo detainees "are being held indefinitely, and without benefit of any legal proceeding to determine their status," id. at 487-88. Although his approach might have appeared at the time to be more limited because it upheld the continuing applicability of World War II precedent, it also gave a stronger hint that application of habeas to Guantanamo had a constitutional basis, viewing it as "necessary corollary" that under some circumstances "courts maintain the power and the responsibility to protect persons from unlawful detention even where military affairs are implicated." Id. at 487.

108 Id. at 481-82 (citations omitted). 
and others like them around the world, challenging actions and events far away, and forcing the courts to oversee one aspect of the Executive's conduct of a foreign war. ${ }^{109}$

Justice Scalia also disagreed with the majority's historical analysis. First, he said, the areas in question were "the sovereign territory of the Crown: colonies, acquisitions and conquests, and so on," adding that "[i]t is an enormous extension of the term to apply it to installations merely leased for a particular use from another nation that still retains ultimate sovereignty." 110 Second, he said, English history demonstrated that " $\mathrm{t}] \mathrm{o}$ the extent the writ's 'extraordinary territorial ambit' did extend to exempt jurisdictions, outlying dominions, and the like, that extension applied only to British subjects." ${ }^{111}$

The debate over history cannot be completely conclusive because the reported cases all involve their own peculiar facts, none of which are exactly parallel to the situation of the Guantanamo detainees. The historical debate is also confusing because the Justices never specify which powers the United States has over Guantanamo or what significance attaches to the purported reservation of "ultimate sovereignty" to Cuba. Presumably, the reservation means that the United States would not be entitled to annex Guantanamo as a part of Puerto Rico or Florida or admit it as a new state. But why this reservation should be critical to habeas jurisdiction is difficult to understand. In any event, it does not appear that England ever held any territories under these specific conditions, nor is it easy to cite an exact analogue from earlier points in U.S. history.

What the history does seem to show is that neither possessing a location outside of formally sovereign territory nor alien status, including citizenship in a hostile nation, was by itself sufficient to defeat habeas jurisdiction. ${ }^{112}$ After a careful review of reported decisions and archival material, legal historians Paul Halliday and G. Edward White concluded that historical understandings of habeas would extend to Guantanamo. ${ }^{113}$ Under English precedent, the primary consideration was the identity of the official detaining the prisoner, not the identity of the prisoner or the location of

109 Id. at 498-99 (Scalia, J., dissenting).

110 Id. at 503.

1 in Id.

112 See Paul D. Halliday \& G. Edward White, The Suspension Clause: English Text, Imperial Contexts and American Implications, 94 VA. L. REV. 575, 672-74 (2008).

113 Id. at 586. 
detention. ${ }^{114}$ Halliday and White also recounted the lessons of some early important American precedents:

First, resident enemy aliens in America, incarcerated because they were citizens of a nation at war with the United States, sought habeas writs to challenge their confinement during the War of 1812. Second, three of the four judges who entertained [these] petitions, including Chief Justice Marshall, concluded that such persons were entitled to test the sufficiency of their detentions through habeas writs. Third, counsel for one of those aliens argued that they were entitled to habeas relief because the Constitution and the "Laws of the Land" mandated that common law judicial power should be available to test the sufficiency of executive detentions. Fourth, Chief Justice Marshall, after having heard this argument, released one of the habeas petitioners, suggesting that he may have retained the distinction between "hostile" and other enemy aliens that was part of the legacy of the Anglo-American habeas jurisdiction at the founding of the Constitution. ${ }^{115}$

"At a minimum," Halliday and White concluded, "the history we have set forth suggests that there should be some opportunity for a judicial inquiry into the circumstances by which a Guantanamo Bay detainee was designated to be eligible for indefinite confinement."116

Thus, history seems to have been on the side of the Rasul majority. But Rasul was not the last act in the Guantanamo habeas drama. Rasul was an interpretation of the existing habeas statute, and as discussed previously, Congress then amended the law and cast doubt on the Rasul holding. Part IV discusses the Court's response in Hamdan to the argument that the statutory amendment mooted habeas petitions that were already pending.

\section{HABEAS CORPUS AND RETROACTIVITY IN HAMDAN}

In Rasul, the Court held that habeas jurisdiction extended to detainees at Guantanamo. The holding, however, was imperiled by a subsequent statutory amendment. The amendment took effect while a habeas appeal was actually pending at the Court. This appeal presented the question of whether the statutory amendment applied retroactively to deprive the Court of jurisdiction over pending cases.

114 See id.

115 Id. at 712.

116 Id. at 714. 
This Part considers the Court's treatment of the retroactivity issue in Hamdan. The dispute between Justices Stevens and Scalia about this issue provides an ideal setting for probing the jurisprudential differences between the Justices and how those differences relate to adherence to the rule of law.

The facts of the case were simple. Hamdan sought habeas in order to challenge the government's effort to try him before a military commission as an unlawful combatant. Three months after the Court agreed to hear the case, Congress passed the Detainee Treatment Act ${ }^{117}$ ("DTA"). The government moved to dismiss the writ of certiorari, arguing that DTA subsection 1005(e)(1) had stripped the Court of jurisdiction to consider Hamdan's habeas petition. That section provides that "no court... shall have jurisdiction to hear or consider ... an application for ... habeas corpus filed by ... an alien detained ... at Guantanamo Bay." 118

The statutory interpretation issue would have been simpler if Congress had added either "regardless of when the petition was filed" or "with respect to petitions filed after this act goes into effect." But instead of including clarifying language, Congress further confused the issue of the application of already filed petitions. Section $1005(\mathrm{~h})(2)$ of the DTA provided that two other subsections, subsections 1005(e)(2) and (3), gave the D.C. Circuit "exclusive" jurisdiction to review the final decisions of military convictions or final detention decisions and applied with respect to any claim whose "review is ... pending on" the DTA's effective date, as was Hamdan's case. ${ }^{119}$ Congress passed the DTA after Rasul, so the question of statutory habeas jurisdiction remained unsettled under the statute. Hamdan did not fall within those alternative review mechanisms because he was challenging trial rather than detention, and there was no military conviction in place. It was unclear whether Congress omitted similar language about the application of subsection $1005(\mathrm{e})(\mathrm{l})$ because it considered that application obvious, or because it actually did not want subsection $1005(\mathrm{e})(\mathrm{l})$ to apply to pending cases.

Writing for the majority, Justice Stevens attempted to resolve the issue of legislative intent by concluding that subsection 1005(e)(1) did not apply to pending petitions like Hamdan's, and therefore the Court had jurisdiction to hear Hamdan's appeal. ${ }^{120}$ In his view, the legislative history not only showed that Congress considered the respective

\footnotetext{
117 Pub. L. No. 109-148, 119 Stat. 2680, 2739-44 (2005).

118 Id.

119 Id.

120 Hamdan v. Rumsfeld, 548 U.S. 557, 584 n.15 (2006).
} 
temporal reaches of subsections $1005(\mathrm{e})(1),(2)$, and (3) together at every stage, but also that Congress omitted paragraph (1) from its retroactivity directive only after having rejected earlier proposals that would have made it retroactive. ${ }^{121}$

Justice Stevens also relied on statutory construction to bolster his stance. He rejected the government's argument, based on Schlesinger $v$. Councilman, ${ }^{122}$ that the Court should wait for the completion of the military commission's proceedings before ruling on the validity of those proceedings, reasoning that the comity considerations at play in Councilman regarding the relationship between the military justice system and the federal courts were not present in Hamdan. ${ }^{123}$ In Schlesinger, the Court had rejected an effort to enjoin a court martial, largely because full review would later be available in federal court and because of the special needs of the military to govern its own members. According to Justice Stevens, ordinary principles of statutory construction negated the government's position. He drew a negative inference from Congress's failure to include subsection 1005(e)(1) within the scope of subsection $1005(\mathrm{~h})(2)$. He analogized to Lindh v. Murphy, ${ }^{124}$ in which the Court had declined to apply some aspects of habeas reform to pending petitions by prisoners. If anything, according to Justice Stevens, Hamdan presented stronger evidence than Lindh that Congress had deliberately omitted some provisions from retroactive effect.

The government also argued that the Court should abstain until a final conviction was in place, by analogy to a similar role for courts in court-martialing service members. The Court found the analogy unpersuasive, in part because the need for military discipline was not present and because of the absence of an integrated congressional system of justice for detainees. ${ }^{125}$ Instead, the Court pointed to World War II precedent allowing enemy soldiers who were facing trial within the United States to obtain habeas review before any trial had been held. ${ }^{126}$

Writing separately for the other three members of the majority other than Justice Stevens, Justice Breyer defended the Court against the charge that it was undermining national security:

\footnotetext{
121 Id. at 578-79.

122420 U.S. 738 (1975).

123 Hamdan, 548 U.S. at 585.

124521 U.S. 320,326 (1997).

125 Hamdan, 548 U.S. at $585-88$.

126 Id. at 588.
} 
Congress has denied the President the legislative authority to create military commissions of the kind at issue here. Nothing prevents the President from returning to Congress to seek the authority he believes necessary.

Where, as here, no emergency prevents consultation with Congress, judicial insistence upon that consultation does not weaken our Nation's ability to deal with danger. To the contrary, that insistence strengthens the Nation's ability to determine-through democratic means-how best to do so. The Constitution places its faith in those democratic means. Our Court today simply does the same. ${ }^{127}$

Justice Scalia dissented, insisting that jurisdiction did not exist and defending the legality of the tribunals on the merits. He relied heavily on "[a]n ancient and unbroken line of authority [that] attests that statutes ousting jurisdiction unambiguously apply to cases pending at their effective date." ${ }^{28}$ He insisted:

This venerable rule that statutes ousting jurisdiction terminate jurisdiction in pending cases is not, as today's opinion for the Court would have it, a judge-made "presumption against jurisdiction," that we have invented to resolve an ambiguity in the statutes. It is simple recognition of the reality that the plain import of a statute repealing jurisdiction is to eliminate the power to consider and render judgment-in an already pending case no less than in a case yet to be filed. ${ }^{129}$

Further emphasizing this point, Justice Scalia added:

Though the Court resists the Bruner [v. United States] ${ }^{130}$ rule [which Justice Scalia viewed as a requirement that all statutes restricting jurisdiction apply to pending cases absent a plain contrary statement from Congress], it cannot cite a single case in the history of Anglo-American law (before today) in which a jurisdiction-stripping provision was denied immediate effect in pending cases, absent an explicit statutory reservation. By contrast, the cases granting such immediate effect are legion, and they repeatedly rely on the plain language of the

${ }_{127}$ Id. at 636 (Breyer, J., concurring).

${ }^{228}$ Id. at 656 (Scalia, J., dissenting).

129 Id. at 657.

130343 U.S. 112 (1952). 
jurisdictional repeal as an "inflexible trump," by requiring an express reservation to save pending cases. ${ }^{131}$

He also disagreed with the majority's parsing of the statutory language and legislative history, finding the statutory language unambiguous and the legislative history utterly unreliable. ${ }^{132}$

Justice Scalia considerably overstated the evidence in speaking of "an inflexible trump." 133 Even if Justice Scalia was right about the jurisdictional retroactivity rule, the Court's presumption against habeas repeals in St. Cyr might trump or at least neutralize that rule. But Justice Stevens, for reasons that will probably become apparent only when the archives are opened, chose not to rely on the St. Cyr presumption. His claim to be applying ordinary principles of statutory interpretation depends, then, on whether he or Justice Scalia is right about jurisdictional retroactivity. If Justice Scalia is right, then a special rule of interpretation applies to jurisdiction-stripping statutes, and the outcome in Hamdan can only be justified on the basis of the St. Cyr rule, which the Court silently avoided.

The only way to determine who is correct is through analyzing case law, which is the subject of the next Part. The results suggest a much more nuanced, if not muddled, approach by past courts in addressing jurisdictional retroactivity than Justice Scalia's stark rule. Walt Whitman once wrote that we can see the universe in a blade of grass. ${ }^{134}$ Somewhat less ambitiously, the next Part investigates a large jurisprudential conflict through a small technical issue, although one with large practical consequences.

\section{INVESTIGATING THE HISTORY OF JURISDICTIONAL RETROACTIVITY}

This Part investigates whether the case law supported Justice Scalia's insistence on an ironclad rule that made all statutory restrictions on jurisdiction apply retroactively to all cases pending at the time of passage. This issue was critical to the argument between Justices Stevens and Scalia over the existence of habeas jurisdiction in Hamdan. This Part first examines the early cases discussed by the two Justices and then considers the modern development of retroactivity law as it bears on jurisdictional issues.

131 Hamdan, at 659-60 (citation omitted).

132 Id. at $660-61$.

133 Id. at 658 .

134 Walt Whitman, Leaves of Grass 46 (Wilder Publ'ns, LLC 2007) (1855) ("I believe a leaf of grass is no less than the journey-work of the stars."). 


\section{A. The Early Cases}

Although Justice Scalia cites a number of pre-1900 cases in his Hamdan dissent, both he and Justice Stevens actually discuss only five opinions beyond unadorned citation. Justice Scalia viewed each of the cases as demonstrating the existence of a clear-statement ruling, requiring that restrictions on jurisdiction be applied retroactively to all pending cases unless Congress explicitly provides otherwise. In contrast, Justice Stevens viewed them all as distinguishable or as involving softer presumptions regarding retroactivity.

To truly count as support for Justice Scalia's strong retroactivity rule, an opinion must do more than merely apply a statutory restriction on jurisdiction to pending litigation. As discussed in the preceding Part, Justice Scalia's argument turned on the asserted existence of a clear-statement rule that did not allow the Court to consider more specific indications of congressional intent. A case that holds a jurisdictional statute applicable to pending cases does not necessarily provide evidence in support of Justice Scalia's claim because the case might rest on specific statutory language or other indications of intent rather than on a clear-statement rule. Thus, to support Justice Scalia, a case must articulate a clear-statement rule or at least decline to consider what would appear to be weighty but indirect evidence against retroactivity. ${ }^{135}$

\section{Insurance Co. v. Ritchie}

The oldest of the cases discussed in Hamdan is Insurance Co. v. Ritchie. ${ }^{136}$ Ritchie does contain the language discussed above supporting Justice Scalia, but the case is unusual in that it involves a series of statutes referring to each other rather than simply one statute that repeals jurisdiction conveyed by the other.

Here is the sequence of events as recounted by the Court:

1. An 1833 law gave the circuit courts jurisdiction of all cases in law or equity arising under the revenue laws of the United States. This was apparently a result of the Nullification Crisis.

2. The Internal Revenue Act of 1864 resolved a dispute about whether the 1833 act applied to disputes involving post1833 (i.e., Civil War) taxes. The 1864 act provided that the 
act of 1833 should extend to all cases arising under the laws for the collection of internal duties.

3. Between 1864 and 1866 , the plaintiffs brought suit under the 1864 act.

4. The 1864 act was repealed by an 1866 statute, without any savings clause for pending actions. "And not only was there no such saving," the Court said, but the 1866 statute "expressly provided that the act of 1833 shall not be so construed as to apply to cases' arising under the act of 1864 , or any amendatory acts, 'nor to any case in which the validity or interpretation of such act or acts shall be in issue." "137

It was in this context that the Court said of the 1866 statute:

This is equivalent to a repeal of an act giving jurisdiction of a pending suit. It is an express prohibition of the exercise of the jurisdiction conferred by the act of 1833 in cases arising under the internal revenue laws.

It is clear, that when the jurisdiction of a cause depends upon a statute the repeal of the statute takes away the jurisdiction. And it is equally clear, that where a jurisdiction, conferred by statute, is prohibited by a subsequent statute, the prohibition is, so far, a repeal of the statute conferring the jurisdiction. ${ }^{138}$

Thus, the evidence that Congress wanted to prevent any application of the 1833 statute was unusually strong; it not only repealed the 1864 law that provided for application of that 1833 statute, but also precluded courts from construing the 1833 statute to apply directly.

In short, Ritchie involved more than a simple jurisdictional repeal. Congress clearly was not content to repeal the 1864 act and return the situation to where it was before 1864; instead, it intended to resolve the pre-1864 dispute about interpreting the 1833 act in favor of the government. Unlike the normal jurisdiction repeal, Congress was not content with simply repealing one earlier statute, but instead went back further to eliminate any possible jurisdiction under an even earlier statute, showing an exceptional desire to reach into the past. It is not surprising that the Court gave the jurisdictional repeal fully retroactive effect in this context. This is important because Ritchie is

\footnotetext{
137 Id. at 543-44.

138 Id. at 544 .
} 
one of the key foundations of the argument for a clear-statement rule, yet the context indicates that there was very little room for such a role to operate because Congress's intent was not really open to doubt. Once again, despite dictum in the opinion favoring Justice Scalia, closer inspection reveals that the case was just as consistent with Justice Stevens's emphasis on the intent of Congress.

\section{Railroad Co. v. Grant}

The next oldest case discussed by Justices Stevens and Scalia in Hamdan is Railroad Co. v. Grant. ${ }^{139}$ While that case was pending on appeal, Congress increased the "amount in controversy" requirement for Supreme Court jurisdiction over cases from the District of Columbia courts. The Court dismissed the pending appeal because it failed to meet the new requirement. According to the Court:

It is claimed, however, that, taking the whole of the act of 1879 together, the intention of Congress not to interfere with our jurisdiction in pending cases is manifest. There is certainly nothing in the act which in express terms indicates any such intention. Usually where a limited repeal only is intended, it is so expressly declared.... Indeed, so common is it, when a limited repeal only is intended, to insert some clause to that express effect in the repealing act, that if nothing of the kind is found, the presumption is always strong against continuing the old law in force for any purpose. . . No declaration of any such object on the part of Congress is found in the law; and when, if it had been the intention to confine the operation of what was done to judgments thereafter rendered or to cases not pending, it would have been so easy to have said so, we must presume that Congress meant the language employed should have its usual and ordinary signification, and that the old law should be unconditionally repealed. ${ }^{140}$

This case does support a "strong presumption," but taken as a whole, does not seem to establish as a rule of law that a savings clause is required, and also does not seem to emphasize the fact that a jurisdictional statute was involved. Rather, the Court was simply inferring what it considered the most usual intent by Congress "where a limited repeal only is intended." 141 Moreover, Hamdan seems

\footnotetext{
13998 U.S. 398 (1879); see Hamdan, 548 U.S. at 658.

140 R.R. Co., 98 U.S. at 402-03 (emphasis added).

141 Id. at 402.
} 
distinguishable because the DTA explicitly provided that some other sections did apply to pending cases, showing that Congress did not rely on a judicial presumption that all such provisions were retroactive. Thus, this case seems not to count against Justice Stevens's position.

\section{Hallowell v. Commons}

The next case in line is Hallowell v. Commons. ${ }^{142}$ This case involved a suit on a land claim that was pending when Congress changed the law to make an administrator the sole judge of such claims. The Court did not seem to rely on a general rule, but instead relied on the purpose of the statute and an argument that the statute was not actually adverse to the claimant's interests:

[T] he reference of the matter to the Secretary, unlike the changes with regard to suits upon bonds, takes away no substantive right, but simply changes the tribunal that is to hear the case. In doing so it evinces a change of policy, and an opinion that the rights of the Indians can be better preserved by the quasi paternal supervision of the general head of Indian affairs. The consideration applies with the same force to all cases, and was embodied in a statute that no doubt was intended to apply to all, so far as construction is concerned. ${ }^{143}$

This language seems to distinguish between jurisdictional repeals based on whether they had substantive or merely procedural impacts. The language thus favors Justice Stevens, because in Hamdan the repeal of habeas jurisdiction would clearly do far more than merely remit the petitioner to an equally fair alternative forum - whatever hearings the military provided at Guantanamo could hardly be considered an example of "quasi-paternal supervision."

\section{Bruner v. United States}

Justices Stevens and Scalia discuss only one case postdating World War II, Bruner v. United States. ${ }^{144}$ Bruner involved a claim for overtime compensation by a government employee. ${ }^{145}$ While the case was pending, Congress amended the statute to withdraw jurisdiction from

\footnotetext{
142239 U.S. 506 (1916).

143 Id. at 508.

144343 U.S. 112 (1952)

145 Id. at 113.
} 
the district court and deem the Court of Claims the exclusive forum. ${ }^{146}$ Apart from passages stitching together language from earlier decisions, the Court's explanation consists only of the following:

The Act of October 31, 1951, withdrawing the jurisdiction of the District Court over suits by "employees," did not reserve jurisdiction over pending cases, even though reservation of jurisdiction over pending cases had been held required and later had been made by Congress in respect to the 1898 provisions withdrawing jurisdiction over suits by "officers." Absent such a reservation, only the Court of Claims has jurisdiction to hear and determine claims for compensation brought by employees of the United States even though the District Court had jurisdiction over such claims when petitioner's action was brought. ${ }^{147}$

Bruner's statement of the Court's rationale is thus unclear about whether the Court was applying a presumption or a clear-statement requirement because either would have supported the result.

Bruner does, however, quote cases referring to a "rule," 148 which provided Justice Scalia with justification in arguing that the nineteenth century cases retained at least some validity as late as fifty years ago. In particular, the Bruner Court quotes a passage from Ritchie: "It is clear, that when the jurisdiction of a cause depends upon a statute the repeal of the statute takes away the jurisdiction. And it is equally clear, that where a jurisdiction, conferred by statute, is prohibited by a subsequent statute, the prohibition is, so far, a repeal of the statute conferring the jurisdiction." 149 Taken out of context, that passage from Ritchie seems to argue for making jurisdictional curtailment nearly automatic, although Ritchie gave other reasons for interpreting the statute to apply to pending cases.

Apart from the fact that the Bruner Court quoted the statement in Ritchie out of context, the statement assumes its own conclusion as an argument for a rule of interpretation. The conclusion is supposedly that the new statute repealing the jurisdictional grant applies to pending cases. But the reasoning is completely circular and merely states that there is jurisdiction only if the later statute does not repeal the earlier one. If the later jurisdictional restriction does apply, then there is no statutory basis for jurisdiction and those lawsuits fail; if it

146 Id. at 114

147 Id. at 115 .

148 Id. at $116-17$.

149 Id. at 116 (quoting Ins. Co. v. Ritchie, 72 U.S. (5 Wall.) 541, 544 (1866)). 
does not apply, a statutory basis for jurisdiction still exists under the prior statute. The fact that jurisdiction must be based on some statute logically does not provide any rule of interpretation about whether to interpret statutes repealing jurisdiction as applicable in any given situation.

A basic logical flaw exists with the Bruner Court's effort to use the Ritchie dictum as encompassing an argument for retroactivity (if indeed the Court meant to do so). A rule about the effect of a statute in those cases in which it applies (eliminating a basis for jurisdiction) cannot dictate whether the statute actually does apply. ${ }^{150}$ Logically, the statement "if $X$ then $Y$ " (if the statute applies to pending cases then there is no jurisdiction in those cases) does not tell us whether $X$ is true. ${ }^{151}$ But Bruner offers nothing better if the Court actually had intended to reaffirm what it seemingly thought to be a clear-statement rule. In effect, the Bruner Court seemed to have assumed that the jurisdictional repeal was retroactive, observed that no statutory basis for jurisdiction existed if it was retroactive, and then concluded that the repeal must have been retroactive because no jurisdiction exists after a repeal. In any event, as we will see in the next section, it is not clear that the Bruner Court even really intended to offer a sweeping statement about the effect of jurisdictional repeals because the Court applied a more nuanced approach almost immediately afterwards.

\section{De La Rama Steamship Co. v. United States}

In interpreting Bruner, we cannot ignore another nearly contemporaneous ruling by the same Justices. A year after Bruner, in a case that Justices Stevens and Scalia failed to cite, the Court tempered Bruner in De La Rama Steamship Co. v. United States, ${ }^{152}$ a unanimous opinion authored by Justice Frankfurter and joined by Chief Justice Vinson, the author of Bruner. De La Rama concerned an admiralty suit under the War Risk Insurance Act to recover losses for a ship sunk during World War II. ${ }^{153}$ The Act was repealed while the suit was

150 By analogy, a law prohibiting guns in a certain area has the effect of making possession of guns illegal, but knowing that fact does not tell us what specific area is covered by the law.

151 Similarly, the statement "if a statute violates the First Amendment it is void" does not tell us which statutes violate the First Amendment. We have to interpret the First Amendment to determine that, just as we have to determine which cases are covered by a jurisdictional repeal in order to determine whether the court retains jurisdiction.

152344 U.S. 386,387 (1953).

153 Id. at $386-87$. 
pending. ${ }^{154}$ The government argued that the repeal deprived the district court of jurisdiction over the case, and the only tribunal available to the libellant was now the Court of Claims. ${ }^{155}$ The government pointed to Bruner in support of its argument, but the Court explained that Bruner was limited to the repeal of purely jurisdictional statutes and, thus, did not apply in this case. The Court reasoned that the potential award the libellant could recover in the Court of Claims would be substantially less than the award he would recover in the district court. ${ }^{156}$ Therefore, as the Court explained, the substance of his claim was tied up with the tribunal in which he would be heard:

[T]o deny petitioner the opportunity to enforce its right in admiralty and to send it to the Court of Claims instead is to diminish substantially the recoverable amount, since in a district court sitting in admiralty interest accrues from the time of filing suit .... The Government rightly points to the difference between the repeal of statutes solely jurisdictional in their scope and the repeal of statutes which create rights and also prescribe how the rights are to be vindicated. In the latter statutes, "substantive" and "procedural" are not disparate categories; they are fused components of the expression of a policy. ${ }^{157}$

The Court then explained that the intent of Congress in repealing the statute should determine whether the repeal is treated as stripping jurisdiction from a particular tribunal. ${ }^{158}$ Congress had not repealed

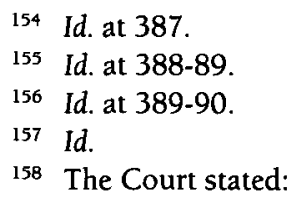

When the very purpose of Congress is to take away jurisdiction, of course it does not survive, even as to pending suits, unless expressly reserved. Ex parte McCardle, 7 Wall. 506, is the historic illustration of such a withdrawal of jurisdiction, of which less famous but equally clear examples are Hallowell v. Commons, 239 U.S. 506, and Bruner v. United States, 343 U.S. 112. If the aim is to destroy a tribunal or to take away cases from it, there is no basis for finding saving exceptions unless they are made explicit. But where the object of Congress was to destroy rights in the future while saving those which have accrued, to strike down enforcing provisions that have special relation to the accrued right and as such are part and parcel of it, is to mutilate that right and hence to defeat rather than further the legislative purpose.

Id. at 390 . 
the War Risk Insurance Act for purely jurisdictional reasons, but rather because it was terminating certain war powers after the end of World War II. ${ }^{159}$ The Court therefore held that the later statute did not apply to pending cases and reinstated the judgment of the district court. ${ }^{160}$

De La Rama demonstrates that just after the Supreme Court articulated the Bruner "rule," it recognized that (a) substance and procedure are not always easily separable, (b) the choice of tribunal may affect the substantive rights of a party, and (c) consideration of actual congressional intent in passing or repealing a statute is critical in determining the procedure-substance distinction and understanding how a change in jurisdictional laws ought to apply to pending cases. Given De La Rama, it seems clear that Justice Scalia was reading too much into Bruner and that Justice Stevens was justified in disregarding the sweeping language of the opinion. If there is a clear-statement rule about jurisdictional repeals in Bruner, it seems to have been limited to cases in which the repeal affects only procedural rights such as the choice of forum rather than any substantive rights.

\section{Lessons Learned from the Early Cases (1800-1955)}

An evaluation of the cases discussed by Justices Stevens and Scalia in Hamdan reveals tenuous support for a clear-statement rule, as the most recent case providing arguable support for such a rule is from the 1950s. Some of the cases contain assertions suggestive of a strong presumption of retroactivity, but in context those assertions do not indicate the strength of any such presumption. These older cases seem to mix somewhat blanket assertions about retroactivity with discussions of specific indicia of congressional intent. Moreover, even by the early 1950s, the Court seemed to vacillate on the existence of a clear-statement rule, relying on the substantive effect of a jurisdictional restriction as a reason to avoid giving the restriction retroactive effect to pending cases. In short, whether the Court had ever embraced a robust clear-statement rule is unclear and, thus, Justice Stevens can hardly be accused of sponsoring an unprecedented departure from hallowed jurisprudential traditions. But the most recent of these cases is over fifty years old. The more recent jurisprudence on statutory retroactivity is discussed next.

159 Id. at 391

160 Id. Another potentially relevant case is United States v. Alabama, 362 U.S. 602 , (1960), in which the Court applied a jurisdiction-granting statute to litigation that was pending when the statute was passed. 


\section{B. Modern (Post-1955) Retroactivity Doctrine}

Even if the earlier cases had provided clearer support against Justice Stevens and stronger support in favor of Justice Scalia's view of jurisdictional retroactivity, the clear-statement approach may not have remained good law by the time Hamdan reached the Supreme Court. The Court's general approach to retroactivity has shifted in the past half century. The older cases apply a general theory of retroactivity that the Court no longer favors. For instance, in older cases such as Grant, the Court stated that the statute was not retroactive because it did not destroy any vested rights. ${ }^{161}$ But the vested right approach has been replaced by a more nuanced approach to retroactivity articulated in Landgraf v. USI Film Products, ${ }^{162}$ which Justice Stevens applied in Hamdan itself.

After Landgraf, the federal circuit courts generally limited the application of Bruner. An investigation of federal appellate cases reveals that the circuit courts have limited applying Bruner to cases where individuals with pending claims still had access to an alternative forum in which to litigate those claims, not where the repeal of a statute left a plaintiff without a forum that could provide adequate relief. ${ }^{163}$ Thus, the circuit courts limited the Bruner rule in a way that brought it closer to Justice Stevens's analysis in Hamdan than to Justice Scalia's analysis.

For instance, the Third Circuit distinguished Bruner in a case involving the repeal of a section of the Truth in Savings Act ("TISA") that provided private causes of action for violations of TISA on precisely this ground:

[U]nlike in Bruner, where the withdrawal of jurisdiction from federal district courts left the plaintiff with an alternate remedy in the Court of Claims ... the repeal of $\S 4310$ [of TISA] not only withdrew the jurisdiction of federal district courts to hear private TISA enforcement actions, but also entirely eliminated the cause of action, thereby releasing a bank from future

\footnotetext{
161 See R.R. Co. v. Grant, 98 U.S. 398, 401 (1878).

162511 U.S. 244, 268-71 (1994).

163 See Santos v. People of Guam, 436 F.3d 1051, 1053 (9th Cir. 2006); Schnall v. Amboy Nat'l Bank, 279 F.3d 205, 209 n.2 (3d Cir. 2002); Yang v. INS, 109 F.3d 1185, 1991 (7th Cir. 1997); Kolster v. INS, 101 F.3d 785, 788 (1st Cir. 1996); Salazar-Haro v. INS, 95 F.3d 309, 311 (3d Cir. 1996); Hincapie-Nieto v. INS, 92 F.3d 27, 29 (2d Cir. 1996); Duldulao v. INS, 90 F.3d 396, 399 (9th Cir. 1996); Phillips Petroleum v. EPA, 803 F.2d 545, 551 (10th Cir. 1986).
} 
claims of private parties to recover actual and statutory damages for TISA violations. ${ }^{164}$

Similarly, the Ninth Circuit cited Bruner when holding that it no longer had jurisdiction to hear appeals from the Supreme Court of Guam after Congress repealed the section of the relevant statute granting it jurisdiction. ${ }^{165}$ But the Ninth Circuit expressly noted that the statute preserved "jurisdiction over the same cases in the Guam court system and review by certiorari in the United States Supreme Court" and, thus, was distinguishable from Bruner. ${ }^{166}$ The Tenth Circuit likewise found that an amendment to the Safe Drinking Water Act's jurisdictional provisions, which required plaintiffs to file in their local circuit court instead of the D.C. Circuit, applied to pending cases, but only because the amendment provided for merely a change in tribunal and did not "affect the ultimate availability of relief for the claims at issue." 167 These lower court analyses are quite consistent with Hughes Aircraft Co. v. U.S. ex rel. Schumer and, thus, with Justice Stevens's approach in Hamdan.

The best support in the circuit courts for Justice Scalia's rule that jurisdictional modifications apply to pending cases is a series of opinions considering petitions for review of deportation filed prior to the passage of the 1996 AEDPA. The act stripped review in any court of alien deportation orders based on particular criminal offenses. ${ }^{168}$ The First Circuit cited to Hallowell and applied the Landgraf test to the AEDPA, stating that "[f]or jurisdictional statutes, the presumption is in favor of immediate application." 169 The court rejected the deportee's argument that this presumption should not apply where a "statute's effect is to deprive a party of access to any judicial review at all."170 Rather, the court said, the AEDPA vests final authority in the Board of Immigration Appeals to hear these claims, and "Landgraf's citation to Hallowell makes us doubtful, absent more guidance from the Supreme Court, that a jurisdictional change from an Article III court to an administrative decisionmaker, in itself, affects the retroactivity

164 Schnall, 279 F.3d at 209 n.2.

165 Santos, 436 F.3d at 1053.

160 Id

167 Phillips Petroleum, 803 F.2d at 551.

168 The section challenged read: "Any final order of deportation against an alien who is deportable by reason of having committed a criminal offense covered in section 241(a)(2) ... (C) . . shall not be subject to review by any court." Antiterrorism and Effective Death Penalty Act of 1996, Pub. L. No. 104-132, \& 440(a), 110 Stat. 1214.

169 Kolster v. INS, 101 F.3d 785, 788 (1st Cir. 1996).

170 Id 
analysis...."171 The Second Circuit reached a similar conclusion, citing Landgraf and Hallowell. ${ }^{172}$

Other circuit courts were in accord. The Third Circuit held that the AEDPA destroyed jurisdiction in pending cases, and in so holding quoted Bruner: "This rule - that, when a law conferring jurisdiction is repealed without any reservation as to pending cases, all cases fall with the law - has been adhered to consistently by this Court." ${ }^{173}$ The court noted, however, that it "carefully reviewed" the section in question to "determine whether Congress provided expressly, or by implication, that the effective date of the section under consideration here would be other than the day of enactment," and found that it had not. ${ }^{174}$ The Seventh Circuit reached the same result, but its analysis was somewhat different. It compared the statutory language of the AEDPA with that of the 1996 IIRIRA, which expressly provided it should not apply solely to proceedings begun after its enactment. ${ }^{175}$ The Seventh Circuit concluded that "the AEDPA covers all cases now in the administrative and judicial pipelines ...."176

Reaching the same result, the Ninth Circuit characterized the relationship between Bruner and Landgraf as thus:

The Supreme Court has long held that "when a law conferring jurisdiction is repealed without any reservation as to pending cases, all cases fall within the law." The Court reaffirmed this "consistent practice" in Landgraf, noting that it has "regularly applied intervening statutes conferring or ousting jurisdiction, whether or not jurisdiction lay when the underlying conduct occurred or when the suit was filed." 177

Because these federal appellate decisions treated Bruner as unimpaired by later decisions, they support Justice Scalia's analysis of jurisdictional retroactivity. Even more notably, they do so in a setting where the result of retroactivity is deprivation of judicial review. However, they seem to fall short of reliance on a clear-statement rule and instead seek other indicators of congressional intent.

171 Id.

172 See Hincapie-Nieto v. INS, 92 F.3d 27, 29 (2d Cir. 1996); see also Mendez-Rosas v. INS, 87 F.3d 672 (5th Cir. 1996) (applying Landgraf analysis with same result).

173 Salazar-Haro v. INS, 95 F.3d 309, 311 (3d Cir. 1996).

174 Id.

175 Yang v. INS, 109 F.3d 1185, 1191 (7th Cir. 1997).

176 Id.

177 Duldulao v. INS, 90 F.3d 396, 399 (9th Cir. 1996) (citations omitted). 
The thrust of these federal appellate deportation opinions is consonant with Justice Scalia's view of the law. But even these cases contain at least hints of qualifications, noting that the aliens would have access to habeas as a way of contesting detention by the government and that the jurisdictional repeal would not apply to claims involving constitutional rights. ${ }^{178}$

Thus, in the years after Landgraf, most circuit courts did not read Bruner as a clear-statement rule governing all jurisdiction-restricting statutes. They qualified Bruner by requiring the existence of an alternative, fully adequate avenue of relief as a predicate for jurisdiction or else considered more specific indications of congressional intent, rather than relying on a clear-statement requirement.

Even more notably, in the 1997 case of Hughes Aircraft Co. v. U.S. ex rel. Schumer, ${ }^{179}$ the Court declined to apply a 1986 law changing qui tam jurisdiction to a pending case. ${ }^{180}$ Moreover, Justice Thomas clearly

178 See, e.g., Hincapie-Nieto v. INS, 92 F.3d 27, 29 (2d Cir. 1996) (quoting government concession that, if detained by the government, the alien could seek habeas); Salazar-Haro v. INS, 95 F.3d 309, 311 (3d Cir. 1996) ("To the extent, therefore, that constitutional rights applicable to aliens may be at stake, judicial review may not be withdrawn by statute.").

179520 U.S. 939 (1997).

180 The Court refused to apply an amendment to the qui tam statute to the case before it because, as Justice Thomas wrote in his opinion for the Court:

We have frequently noted, and just recently reaffirmed, that there is a "presumption against retroactive legislation [that] is deeply rooted in our jurisprudence. ... The 'principle that the legal effect of conduct should ordinarily be assessed under the law that existed when the conduct took place has timeless and universal appeal.' " . . . Accordingly, we apply this time-honored presumption unless Congress has clearly manifested its intent to the contrary ....

Nothing in the 1986 amendment evidences a clear intent by Congress that it be applied retroactively, and no one suggests otherwise. Thus, under the analysis the Court adopted in Landgraf, if the 1986 amendment has a retroactive effect, then we presume it will not apply to the conduct alleged in this case, which occurred prior to its effective date.

Id. at 946.

Another 1997 case involved the application of new habeas rules to pending cases. The dissent argued that "we have regularly applied statutes ousting jurisdiction to pending litigation" and that "[t]here is a good argument that $\$ 2254(\mathrm{~d})$ is itself jurisdictional." Lindh v. Murphy, 521 U.S. 320, 342-44 (1997) (Rehnquist, C.J., dissenting). But the majority took a different approach, concluding that because another habeas restriction was made expressly applicable to pending cases, Congress must have meant other restrictions to apply only to newly filed cases. Id. at 326-28 (majority opinion). The reasoning in Hamdan is quite similar. See Hamdan v. 
rejected the idea that any special retroactivity rules apply to jurisdiction in pending cases. The passage is worth quoting at length because it so strongly favors Justice Stevens's interpretation of retroactivity law in Hamdan:

Finally, respondent contends that the 1986 amendment is jurisdictional, and hence that it is an exception to the general Landgraf presumption against retroactivity.... The fact that courts often apply newly enacted jurisdiction-allocating statutes to pending cases merely evidences certain limited circumstances failing to meet the conditions for our generally applicable presumption against retroactivity, not an exception to the rule itself, as the United States recognizes. ... As we stated in Landgraf:

"Application of a new jurisdictional rule usually 'takes away no substantive right but simply changes the tribunal that is to hear the case.' Present law normally governs in such situations because jurisdictional statutes 'speak to the power of the court rather than to the rights or obligations of the parties.' "181

Thus, Hughes seems consistent with Justice Stevens's rejection of special retroactivity rules for jurisdictional cases.

Significantly, Hughes also distinguishes between different types of jurisdictional statutes in terms of how the normal retroactivity rules apply. The Court clearly differentiated between forum selection and other jurisdictional changes:

Statutes merely addressing which court shall have jurisdiction to entertain a particular cause of action can fairly be said merely to regulate the secondary conduct of litigation and not the underlying primary conduct of the parties.... Such statutes affect only where a suit may be brought, not whether it may be brought at all. The 1986 amendment, however, does not merely allocate jurisdiction among fora. Rather, it creates jurisdiction where none previously existed; it thus speaks not just to the power of a particular court but to the substantive rights of the parties as well. Such a statute, even though

\footnotetext{
Rumsfeld, 548 U.S. 557, 584 (2006).

181 Hughes Aircraft Co., 520 U.S. at 950-51.
} 
phrased in "jurisdictional" terms, is as much subject to our presumption against retroactivity as any other. ${ }^{182}$

Therefore, Hughes makes two key points. The first is Justice Thomas's insistence that jurisdictional rules are subject to the same retroactivity principles as other statutes. This holding undermines Justice Scalia's claim in Hamdan that retroactivity of jurisdictional statutes is the subject of a unique clear-statement requirement. This holding also strongly supports Justice Stevens's position that normal retroactivity rules apply. The other key aspect of the opinion is Justice Thomas's sharp distinction between jurisdictional statutes that merely affect choice of forum and those that impact substantive rights, which is akin to Justice Stevens's argument in Hamdan.

Consequently, Hughes strongly supports Justice Stevens's analysis of the retroactivity issue in Hamdan. The abolition of habeas jurisdiction in Hamdan clearly did more than change forums because no judicial remedy remained available to detainees as of right if they received a sentence lower than ten years in their trials. Hence, a substantial change in rights resulted. Prior to the amendment, defendants who received such sentences had judicially enforceable rights, including the right not to be tried for invalid charges, while after the amendment they could only hope for discretionary review. ${ }^{183}$ Moreover, Hughes emphatically does not embrace any special clear-statement rules for jurisdictional retroactivity.

It is true that Hughes also distinguishes between expansion of jurisdiction resulting in new liability and other jurisdictional issues, similar to Hamdan. But Hughes does not embrace Justice Scalia's mechanistic distinction between statutes expanding jurisdiction and those contracting it. Rather, the Court's rationale was that the particular expansion of jurisdiction involved in Hughes changed the rules governing primary behavior, not just the rules about secondary behavior pertaining to the conduct of litigation. ${ }^{184}$

This nuance further emphasizes Justice Thomas's view that jurisdictional laws are not an exception from normal retroactivity rules. Rather, jurisdictional laws involve a special application of those rules, and jurisdictional rules affecting substantive rights are quite different from those merely affecting the choice of forum. In Hughes, the Court clearly disavowed the existence of special retroactivity rules governing jurisdiction except to the extent that those rules could be

\footnotetext{
182 Id.

183 Hamdan, 548 U.S. at 572-75.

184 Hughes Aircraft Co., 520 U.S. at 951-52.
} 
justified as applications of the Court's general approach to retroactivity. The next Subpart discusses the relevance of this history to the disputes between Justice Stevens and Justice Scalia in Hamdan.

\section{Interpreting Justice Stevens's and Justice Scalia's Reliance on History}

In light of the evidence presented in the preceding two subparts, the fairest interpretation of the arguments of Justices Scalia and Stevens is as follows. In the nineteenth century, there was a strong presumption - how strong is difficult to say - that statutes limiting jurisdiction applied to all pending cases. No real reason for the presumption existed except a sense that Congress normally included savings clauses when it wanted a different result - thus, the basis was a perception of normal congressional practice. The Supreme Court rarely invoked the presumption after 1900, although the Court reiterated it in one 1950 case (Bruner) and partially limited it almost immediately thereafter (in De La Rama). Furthermore, by 1986 - two decades before Hamdan the Court had blurred the idea that special retroactivity rules apply to jurisdictional issues without pausing to call for a difference in outcomes depending on whether jurisdiction had been expanded rather than contracted. A decade before Hamdan, the Court seemed to repudiate the idea that special retroactivity tests apply to jurisdictional statutes, which it seemingly reaffirmed in a recent case, Republic of Austria v. Altmann, allowing retroactive application of the Foreign Sovereign Immunity Act. ${ }^{185}$

185 The Court again drew no distinction between expansion and contraction of immunity:

In contrast, we sanctioned the application to all pending and future cases of "intervening" statutes that merely "confe $[\mathrm{r}]$ or ous $[\mathrm{t}]$ jurisdiction." Landgraf v. USI Film Products, 511 U.S. 244, 274 (1994). Such application, we stated, "usually takes away no substantive right but simply changes the tribunal that is to hear the case." Id. (internal quotation marks omitted). Similarly, the "diminished reliance interests in matters of procedure" permit courts to apply changes in procedural rules "in suits arising before [the rules'] enactment without raising concerns about retroactivity." Id. at 275 .

Balancing these competing concerns, we described the presumption against retroactive application in the following terms:

"When a case implicates a federal statute enacted after the events in suit, the court's first task is to determine whether Congress has expressly prescribed the statute's proper reach. If Congress has done so, of course, there is no need to resort to judicial default rules. When, however, the statute contains no such express command the court must determine whether the new statute would have retroactive effect, i.e., whether it would impair rights a 
One reason why having a special rule for jurisdictional cases makes little sense is that the difference between a jurisdictional rule and a substantive rule is often unclear, as recognized in many of the recent federal appellate opinions discussed above. For instance, in Hughes (the qui tam case), the so-called jurisdictional change eliminated what would otherwise have been a defense of prior disclosure. ${ }^{186}$ Similarly, eliminating jurisdiction to challenge a tax allows the government to collect revenue to which it may not be legally entitled. ${ }^{187}$ The issues in these cases pertain not only to the choice of forum, but also to the substantive rights of parties whose claims are denied jurisdiction.

Similarly, eliminating habeas jurisdiction is not simply a matter of modifying the allocation of authority to courts. Rather, the writ of habeas corpus is closely related to the right to be free from arbitrary executive detention. Commentators vigorously argue today whether a suspension of the writ leaves any substantive right in existence even as a theoretical matter, let alone as a matter of practical reality. ${ }^{188}$ Although the DTA provided for judicial review after conviction, it provided no avenue for review to individuals who were simply held indefinitely without charge or without a formal determination of unlawful combatant status. ${ }^{189}$ Individuals who were charged with

party possessed when he acted, increase a party's liability for past conduct, or impose new duties with respect to transactions already completed. If the statute would operate retroactively, our traditional presumption teaches that it does not govern absent clear congressional intent favoring such a result." Id. at $280,114 \mathrm{~S}$. Ct. 1483.

Republic of Austria v. Altmann, 541 U.S. 677, 693-94 (2004).

186 See Hughes Aircraft Co., 520 U.S. at 950-51.

187 See Ins. Co. v. Ritchie, 72 U.S. (5 Wall.) 541, 542-44 (1866).

188 See, e.g., Trevor W. Morrison, Suspension and the Extrajudicial Constitution, 107 CoLUM. L. REV. 1533, 1535-36 (2007) (arguing that suspension of habeas does not affect underlying legality of detention); David L. Shapiro, Federal Courts, Practice $\mathcal{E}$ Procedure: Habeas Corpus, Suspension, and Detention: Another View, 82 NOTRE DAME L. REv. 59, 60-61 (2006) (arguing that it does).

189 See Detainee Treatment Act, Pub. L. No. 109-148, 119 Stat. 2680 (2005). As amended by the MCA, 28 U.S.C. $\$ 2241$ (e) precludes judicial review of detainment of alleged enemy combatants except as provided by subsections 1005(e)(2) and (3) of the DTA. Those subsections of section 1005 (which are set out in the Note following 10 U.S.C. \& 801) provide for reviews of final decisions by military commissions and combatant status review tribunals. Under subsection (e)(2)(B)(ii), review for detainees who have not been convicted by military commissions is limited to claims by an alien "for whom a Combatant Status Review Tribunal has been conducted, pursuant to applicable procedures specified by the Secretary of Defense." Thus, if no tribunal review has occurred, no review is available under these provisions, and as noted above, $\$ 2241(\mathrm{e})$ precludes any other judicial relief. Hence, if an alien is simply held indefinitely without any proceeding, no judicial review is available. 
offenses would be forced to stand trial under unlawful procedures before they could obtain any remedy under the new postconviction process.

The ultimate postconviction review would also be less satisfactory than habeas. The procedural differences between the novel form of postconviction review in the new statute and traditional habeas review also limited the ability of detainees to establish violations of their rights even when the new procedure would have been available, a point that ultimately led the Court in Boumediene to hold the new review provision unconstitutional. ${ }^{190}$ Because the new review provision provided a less adequate form of protection of substantive rights, the switch from traditional habeas to the new form of postconviction review cannot be considered merely a matter of procedure rather than substance. Thus, under the modern interpretation of Bruner, the jurisdictional revision should be classified as substantive rather than purely procedural, and for that reason, it should not apply to pending cases.

In short, Justice Stevens seems to be on solid ground, while Justice Scalia seems to have overstated the historical clarity and severity of the presumption in favor of applying jurisdiction-restricting statutes to pending cases. Justice Scalia was able to point to only one arguable Supreme Court application of this presumption within the lifetimes of the current Justices. In contrast, the most recent Supreme Court opinion in Hughes, while perhaps factually distinguishable from Hamdan, squarely repudiates the concept that jurisdictional statutes are subject to special retroactivity rules. To the extent that Congress is aware of Supreme Court interpretation rules when it drafts statutes, it would not have believed in 2005 that any special rule applied to the application of statutes restricting jurisdiction to pending cases.

This may seem like a fine point, but it is important because it addresses Justice Scalia's claim that Justice Stevens was flouting a bright-line legal rule in upholding jurisdiction in Hamdan. The most that can be said is that Justice Stevens gave little weight to a somewhat unclear and archaic rule - a rule that (1) was articulated without much justification and in varying forms; (2) was almost entirely found in century-old decisions, which themselves might be factually distinguishable; (3) was based mostly on a nineteenth century congressional drafting practice that might or might not continue today; and (4) is inconsistent in approach with the language of more recent opinions, particularly Justice Thomas's opinion in Hughes.

190 See Boumediene v. Bush, 128 S. Ct. 2229, 2234-39 (2008). 
When one sets aside this purported clear-statement rule, Justice Stevens's opinion demonstrates that at least the DTA's text is ambiguous about the application of the habeas repeal to pending cases, given that adjacent subsections also involving jurisdiction expressly apply to pending cases. The legislative history shows that at least some legislators prior to passage gave the law this interpretation, especially because their statements were not contradicted at the time. Reasonable people might differ about the weight to be given the negative inference or the legislative history, but Justice Stevens's conclusion is at least a reasonable one even without the St. Cyr interpretative canon that limits on habeas should be read narrowly. A clinching factor is that Congress imposed new procedures in lieu of habeas, which seem designed to make the system more orderly and efficient - a purpose that would be served by allowing the Court to decide in the pending case whether the military commission process created by Congress was valid. The alternative would be to wait to consider these issues until trials were already concluded, potentially requiring the whole process to be redone if the Court found the tribunals defective.

Thus, Justice Stevens's analysis was well founded in terms of conventional statutory interpretation. Perhaps at least some members of Congress nevertheless expected that jurisdiction-stripping would apply to pending cases, but it would have been unreasonable for them to assume the courts would necessarily reach that result. The outcome of Hamdan should have been no surprise. If Congress did mean to eliminate jurisdiction over pending cases, it was foolish to include language about pending cases that applied to other subsections but not include any such language in this one. Clearly, the Court saw itself in Hamdi and Rasul as playing a critical role in policing the government's treatment of detainees. Thus, congressional proponents of retroactivity had little reason to assume that statutory silence would favor them, whereas opponents of retroactivity had good grounds for thinking that the courts would interpret silence as precluding retroactivity.

In passing legislation, Congress should be able to rely on existing legal rules of interpretation. Otherwise, Congress has no way of anticipating how statutes will be applied. Congress should have been aware from St. Cyr and Lindh that the Court was willing to read habeas-restrictive statutes with a magnifying glass, such as narrowly distinguishing "habeas" from "judicial review" in St. Cyr. Despite the fact that Justice Stevens later failed to rely on St. Cyr's canon that restrictions on habeas must be stated clearly, Congress (or wellinformed staff members) should have known about this rule as well. On the other hand, Congress had no reason to be aware of a rule 
regarding jurisdiction that the Supreme Court had last invoked fifty years ago in an obscure opinion. A reasonable member of Congress would have anticipated the likelihood that the habeas restriction would apply only to future cases and would have understood the need for clarifying language if the statute was meant to apply to pending cases instead.

Justice Stevens claimed in Hamdan to be following existing law. If Justice Scalia were right about the existence of a clear-statement rule, Hamdan would have been a questionable ruling and would have upset the justifiable expectation of at least some members of Congress that the habeas restriction would apply to all pending cases. But in reality, the clear-statement rule had a muddled history prior to the midtwentieth century, and any presumption in favor of retroactivity was further undermined by circuit court decisions until the Supreme Court itself rebuffed the idea of unique rules for jurisdictional retroactivity in Hughes.

Thus, Justice Scalia's approach - not Justice Stevens's - would have been a startling departure from current legal understanding. Justice Stevens, rather than Justice Scalia, was true to the rule of law in his approach to this technical issue. As discussed below, he was also more true to the rule of law in a larger sense.

\section{CONCLUSION}

Habeas jurisdiction became a key point of contention in debates over Guantanamo from the time that the Bush Administration chose that location with the aim of foreclosing jurisdiction. In two critical opinions written by Justice Stevens, the Supreme Court first held that statutory jurisdiction extended to Guantanamo and then refused to give retroactive effect to a jurisdiction-stripping statute. Later, the Court built on those two decisions to hold that a more definitive jurisdiction-stripping statute was unconstitutional. Justice Stevens played a critical role in the struggle to keep the courthouse doors open to detainees and demonstrate that American law would not tolerate the disposal of prisoners to a legal black hole. In the course of these decisions, Justices Stevens and Scalia dueled over the interpretation of jurisdictional statutes, with each implying that the other was distorting the law to reach a preferred result.

These post-9/11 cases pursue debates about the rule of law at a range of scales. At the smallest scale, the debate was over whether it was Justice Stevens's majority opinion in Hamdan or Justice Scalia's dissent that correctly stated the law regarding the application of jurisdictional changes to pending cases. This was also a debate about 
what a reasonable member of Congress would have understood the legislation to mean. At an intermediate level, the debate was first about whether the great writ of habeas corpus extended as a matter of statute - and later, as a matter of constitutional law - to alien detainees held by the executive in Guantanamo for alleged violations of the laws of war. And at the highest level, the debate was over whether the President can respond to a perceived national security threat free from any legal constraint other than his own view of the national interest. At all these scales from legal technicality to political philosophy, the issue was the viability of the rule of law. And at all these scales, Justice Stevens stood staunchly in favor of the rule of law.

Justice Stevens's post-9/11 habeas opinions have occasional flights of rhetoric, but for the most part they read like routine applications of technical legal reasoning. The rules regarding application of jurisdictional statutes to pending cases, for instance, are hardly the stuff of newspaper headlines. Yet this rhetorical flatness is entirely in tune with the fundamental point of these decisions, which is that "the law" remains in effect and applicable even in times of crisis when national security is at stake. And "the law," by and large, is boring and complicated. What these opinions stand for, both in rhetoric and in substance, is an insistence that the government abide by the law of the land. In particular, the government must respect the right of individuals to be heard in their own defense.

These procedural rights are sometimes undervalued by those who are hasty to seek support for their views of social policy. ${ }^{191}$ But Justice Stevens's approach can be shared by those of varying ideologies. Thus, the great Marxist historian E.P. Thompson repudiated standard leftist skepticism about the legal system - much to the distress of some of his ideological cohort in the American legal academy ${ }^{192}$ — when he said:

I am insisting only upon the obvious point, which some modern Marxists have overlooked, that there is a difference between arbitrary power and the rule of law. We ought to expose the shams and inequities which may be concealed beneath this law. But the rule of law itself, the imposing of effective inhibitions upon power and the defence of the citizen from power's all-intrusive claims, seems to me to be an

191 For an enlightening discussion of this issue, see Jenny S. Martinez, Process and Substance in the "War on Terror," 108 CoLum. L. REv. 1013 (2008).

192 See Morton J. Horowitz, An Unqualified Human Good?, 86 YAlE L.J. 561, 566 (1977) (complaining that "I do not see how a Man of the Left can describe the rule of law as 'an unqualified human good" " and calling this "surprising and disturbing" step). 
unqualified human good. To deny or belittle this good is, in this dangerous century when the resources and pretensions of power continue to enlarge, a desperate error of intellectual abstraction. ${ }^{193}$

Justice Stevens, while rejecting E.P. Thompson's ideology root and branch, would likely embrace this conclusion. Alas, it is now conservatives such as Justice Scalia rather than Marxists who seem willing to sacrifice the rule of law to achieve their policy goals. Fortunately, it was Justice Stevens's view that prevailed in the Supreme Court. 